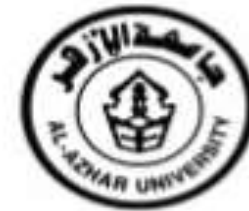

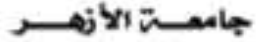

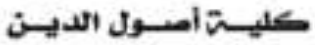

$$
\begin{aligned}
& \text { والد صوة الإسلاميت بالعنوفيتي }
\end{aligned}
$$

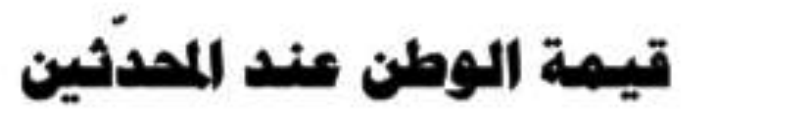

بعلم المكتور

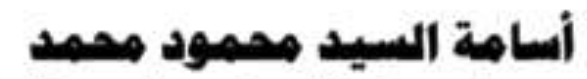

مدرب الحلفيث الثير يف وعلومه بكليت أصول الدين بالززقازيق الصرديق 



\section{in in}

إن للأوطان قيمة عليا، تكثف عن نبل طبع الرجال، ومعادن الأبرار منهم، وتستنهض في النفوس أشرف معاني البر والوفاء.

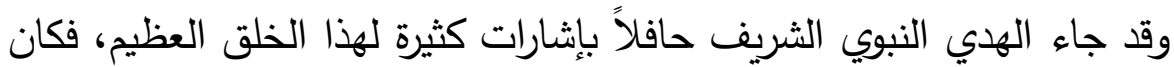
حب الأوطان مما علمه (ئسئ) لأصحابه، وتشربوه منه وأقرهم عليه. ولما أن المحدثون أقرب الناس إلى هدي النبوة الثريف، وأكثر الناس مخالطة لله، ولحديثه وسنته المشرفة، كان إستجلاء قيمة الوطن من خلال شروحهم للحديث النبوي الثريف. وقد شاعت في السنوات الماضية مقولات ظالمة، من نتاج فكر تيارات التطرف، تتكر قيمة الوطن، وتشوهها، وتصغرها في النغوس، مما أوجب على الباحثين النهوض إلى إستجلاء فكرة الوطن ونظرة أئعتا إليها، من خلال الغوص وه وهن في كتب علومهم على إختلاف فنونها ومجلاتها، لإبراز ثمرات العقول السليمة المستنيرة بهدي النبوة وأنوارها عند النظر إلى هذه القئ القضية. ومن هنا جاء هذا البحث حول قيمة الوطن عند الحفاظ والمحثثن، ييرز عظم مكانة الوطن عندهم، وأنهم بذلوا جهود جليلة للكثف عن القيمة الأخلاقية النبيلة.

$$
\text { وقد قسمته إلى عدة مباحث وهي: }
$$

المبحث الأول: جمع كلام الحفاظ والمحدثين وشراح الحديث عن قيمة الوطن

$$
\text { وترتيبه على مسائل. }
$$

المبحث الثاني: ذكر طائفة من المحدثين برز عندهم ملمح حب الوطن،

فتناقله المحدثون بعدها عنهم ومدحوهم به. المبحث الثالث: في الكتب والمؤلفات التي أفردها الحفاظ والمحدثون وغيرهم عن الوطن، وأكثر المصنفين في هذا المبحث من المحدثين. 
قيمة الوطن عند المحدثّين

المبحث الرابع: في نبذة من كلام المفسرين والفقهاء والزهاد وبقية أرباب العلوم عن الوطن. 


\section{ABSTRACT}

The people have a high value, revealing the nobility of printing men, the minerals of the righteous, and rise in the souls of the righteousness and fulfillment.

The Prophet's guidance was replete with many references to this great creation, and the love of the Prophet (PBUH) was taught to his companions, drank from him and acknowledged.

As the people who are the closest to the Holy Prophet, and the many people in contact with him, and for his talk and his honorable year, the value of the homeland was clarified through their commentaries to the Prophet's hadith.

In the past years, unjust arguments have become commonplace, resulting from the ideology of extremist currents, denying the value of the nation, distorting it, and giving it a glimpse into the souls, forcing the researchers to seek to clarify the idea of the homeland and look at it, by diving in their science books of different arts and magazines, to highlight the fruits of the sulay minds. Enlightened by the guidance of the prophecy and its lights when looking at this issue.

Hence, this research on the value of the nation when preserving and the modernstates, highlights the great place of the country and they have made great efforts to uncover the noble moral value.

It was divided into several detectives:

The first is to collect the words of preservation and the hadith and commentators about the value of the country and its arrangement on issues

The second discourse: a group of scholars who have emerged as a feature of the love of the homeland, and then passed by the Moderners and praised them.

The third discourse: in the books and literature, which are devoted by the preservation, the modernists and others about the country, and the most classified in this discourse of the fourth discourse: in a glimpse of the words of the interpreters and the scholars and the Masters and the rest of the scientists about the country ... 


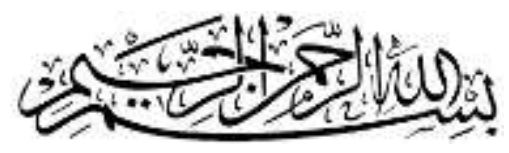 \\ |}

الحمــ لله رب العـالمين، والصـلاة والسـلام على سـيدنا محمد سـيد الأولـين والآخرين، وختام الأنبياء والمرسلين، ورحمة الله تعالى للعالمين، وعلى آله وصحبه ومن تبعهم بإحسان إلى يوم الدين.

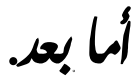

فإن للأوطان قيمة عليا، تكثف عن نبل طباع الرجال، ومعادن الأبرار منهم، وتستنهض في النفوس أشرف معاني البر والوفاء، والنفوس مجبولة على الامتنان لسوابق الإحسان. وقد جاء الهدي النبوي الشريف حافلا بإشارات كثيرة لهذا الخلق العظيم، حيث جاء صلوات الله وتسليماته عليه بكل بر وإحسان وعرفان، كان حب الأوطان مما

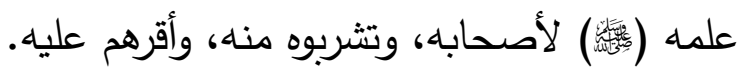

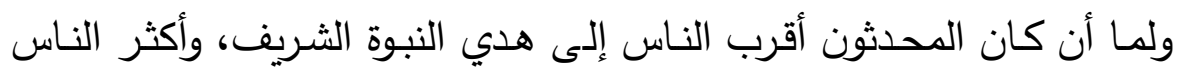
مخالطـة لـه، ولحديثهـه وسـنته المشـرفة، كـان اسـتجلاء قيمـة الـوطن مـن خـلال شروحهم للأحاديث، وتآليفهم، من محاسن الأمور • وقد شـاعت في السـنوات الماضـية مقولات ظالمـة، مـن نتـاج فكر تيـارات التطرف، تتكر قيمـة الوطن، وتشوهها، وتصـغرها في النفوس، ممـا أوجب على على الباحثين النهوض إلى استجلاء فكرة الوطن ونظرة أئمتتا إليها، من خلال الغوص في كتب علومهم على اختلاف فنونها ومجالاتها، لإبراز ثمرات العقول السليمة المستتيرة بهدي النبوة وأنوارها عند النظر إلى هذه القضية. 
ومن هنـا جاء هذا البحث حول قيمـة الوطن عند الحفاظ والمحدثين، يبرز عظم مكانة الوطن عندهم، وأنهم بذلوا جهودا علمية جليلة للكثف عن هذه القيمة الأخلاقية النبيلة، وقد قسمته إلى عدة مباحث:

المبحث الأول: جمع كلام الحفاظ والمحثين وشراح الحديث عن قيمة الوطن وثن وترتيبه على مسائل.

المبحث الثاني: في ذكر طائفة من المحدثين برز عندهم ملمح حب الوطن، فتناقله المحدثون بعدها عنهم ومدحوهم به. المبحث الثالث: في الكتب والمؤلفات التي أفردها الحفاظ والمحدثون وغيرهم عن الوطن، وأكثر المصنفين في هذا الباب من المحدثين. المبحث الرابع: في نبذة من كلام المفسرين والفقهاء والزهاد وبقية أرباب العلوم عن الوطن.

\section{C)}




\section{الامبـث الأول}

\section{بمع كلام المفاظ والمدثين وشثراج المديث عن قيسمة الوطنث}

\section{وترخيبه على مساثل}

* مسئلة في استنباطهم قيمة الوطن من حديث: (كان إذا قدم من سفر): روى الإمام البخاري وابن حبان في صحيحيهما والترمذي في سننا والنسائي

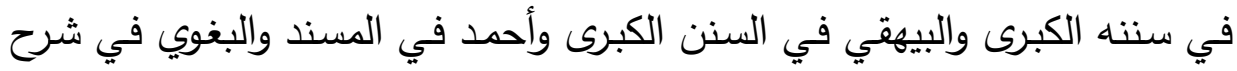

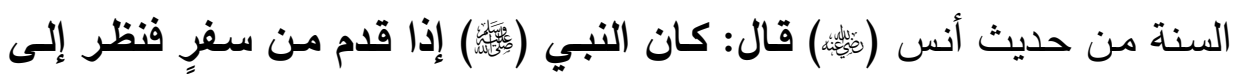

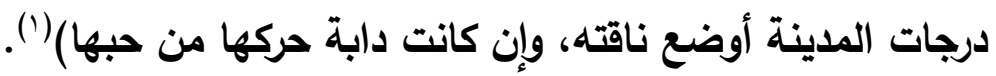

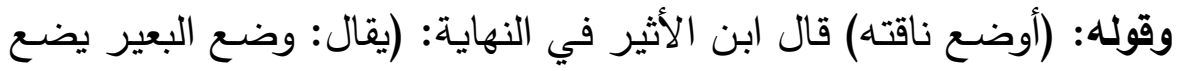

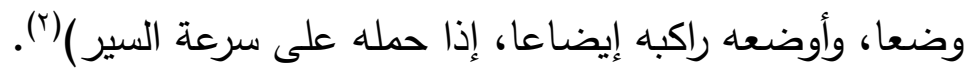

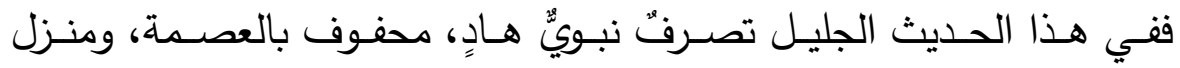

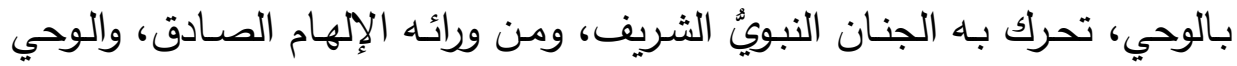

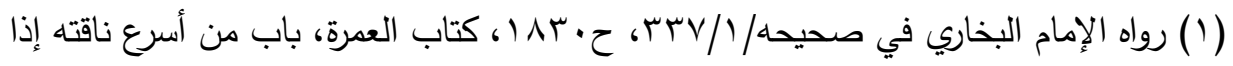

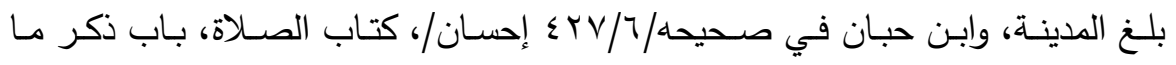

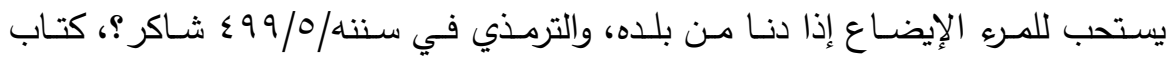

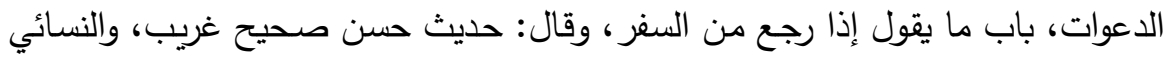

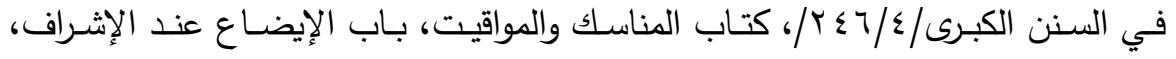

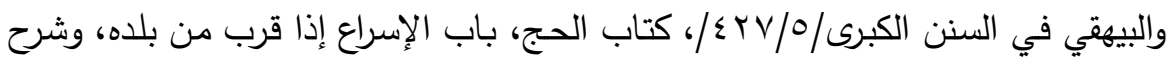

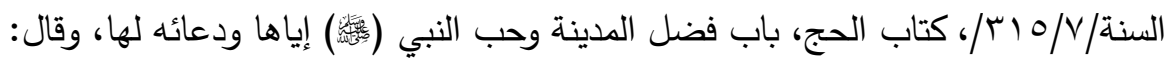

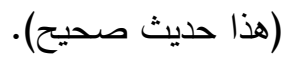

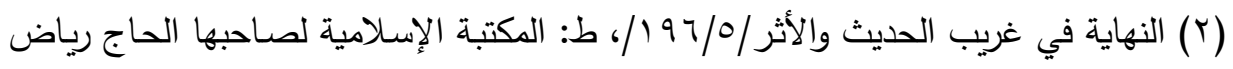

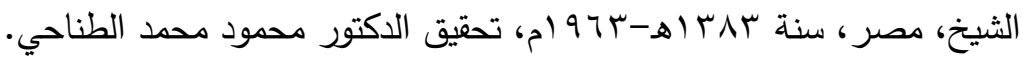




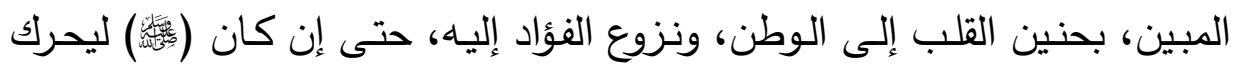

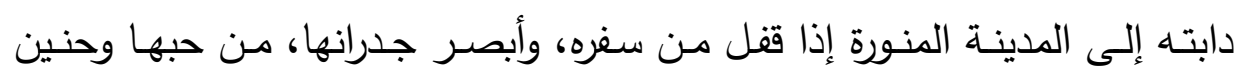
الجنان الثريف إليها.

ولذلك قال ابن بطال في شرح صحيح البخاري: (واحتج من فضل المدينة بقوله: "حركها من حبها" يريد من حبه للمدينة، قال: فقد خصها الله بفضائل كثيرة،

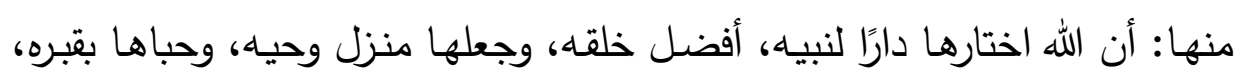
ومنها نشر الله دينه وبَلَّغ شريعته، إلى ما لا يحصى من فضـائلها، وتعجيل سيره

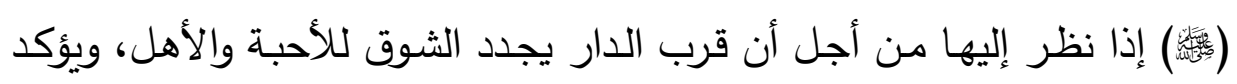

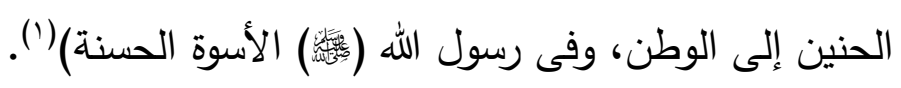
وقال الحافظ ابن حجر في: (فتح الباري، في شرح صديح البخاري): (وفي الحديث دلالة على فضل المدينة، وعلى مشروعية حب الوطن، والحنين إليه)(ب)، ونحوه عند البدر العيني في عمدة القاري(ז). فهذه شذرات من كلام المحدثين في شرح هذا الحديث الجليل، وأنه دالُّ ومرشدُّ إلى حظ مـن السـن النبويـة المشـرفة، يتجـاور مـع بقيـة السـن الثـريفة المتعلقـة

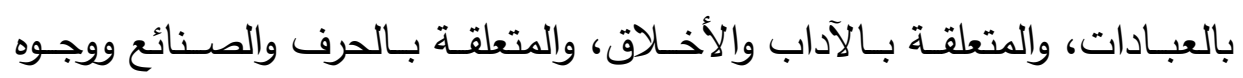

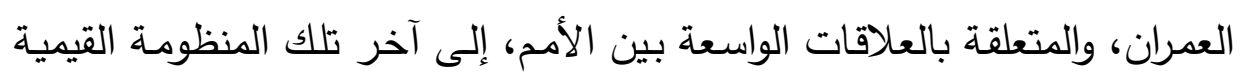
النبوية، الصانعة لشخصية الإنسان المسلم على حد التمام والكمال.

(1) شرح صحيح البخاري لابن بطال/\&/000، ط: مكتبة الرشد، الرياض، المملكة العربية السعودية، سنة ضبط نصه وعلق عليه: أبو تميم ياسر إبراهيم.

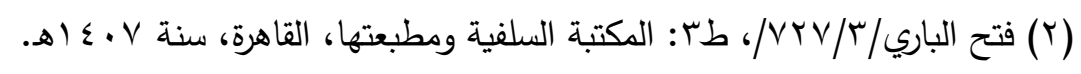

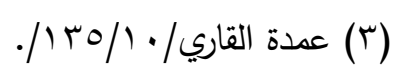


قال الحافظ الأهبي في: (سير أعلام النبلاء): (وكان يحب عائشة، ويحب أباها، ويحب أسامة، ويحب سبطيه، ويحب الحلواء، والعسل، ويحب جبل أحد، ويحب وطنه، ويحب الأنصار ، إلى أشياء لا تحصى، مما لا يغني المؤمن عنها قط)('). فكثف الحافظ الذهبي هنا في هذه العبارة الذهبية عن جواهع من الهدي النبوي، تبين أن الجنان النبوي الثريف المنير بأنوار النبوة الباهرة، والعصمة الظاهرة، قد فاضت عنه المعاني النبيلة في حب زوجه المطهرة السيدة عائشة، وأبيها الصديق، والحب بن الحب أسامة بن زيد، وكان يحب الحلواء والعسل، وجبل أحد، والوطن، والأنصار ، وغير ذلك، والمشاعر التي تفيض عن الجنان النبوي لا يخالطها هوى، فهي أصح المشاعر وأكثرها انطباقا على المراد الإلهي. ***** * *

* مسئلة في استنباطهم قيمة الوطن من حديث (تلاثة تستجاب دعوتهم) فذكر

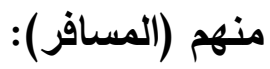

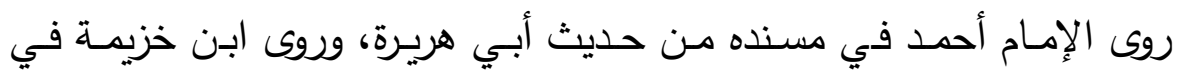
صحيحه، والروياني في مسنده، والطبراني في معجمه، والبغوي في شرح السنة،

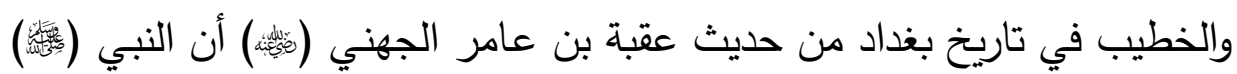
قال: (ثلاثة تستجاب دعوتهم: الوالد، والمسافر، والمظلوم)(؟).

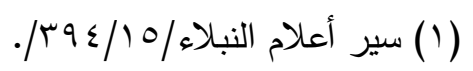

(r) ورد الحديث من مسندي أبي هريرة وعقبة بن عامر (برئما)، أما حديث أبي هريرة فقد رواه

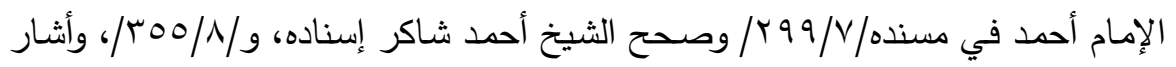

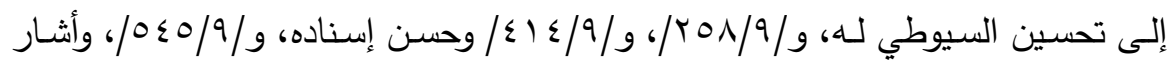

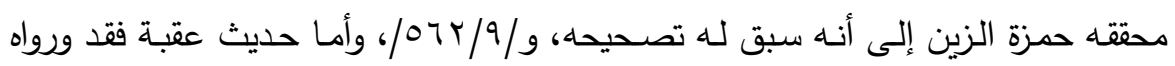

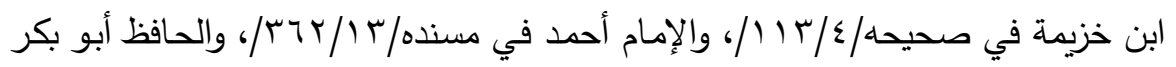

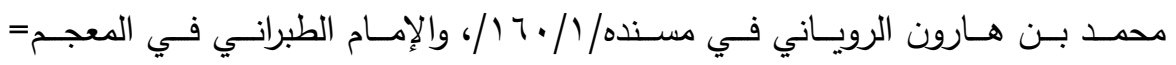


جعل العلماء حب الوطن هو علة مشقة السفر مطلقا، حتى لقد ذهب إلى ذلك بعض شراح الحديث في تفسير هذا الحديث، فعلل الشراح سبب استجابة دعاء

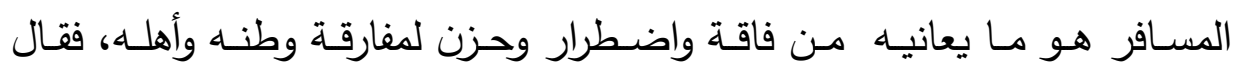
العلامـة المحدث المنـاوي في: (فـيض القدير ، شـرح الجـامع الصـغير) شـارحًا للحديث: (لأن السفر مظنـة حصسول انكسـار القلب بطول الغربـة عن الأوطسان، وتحمل المشاق والانكسار من أعظم أسباب الإجابة)('). فبرزت هنا قيمة الوطن، وأنها معنى مقصود في تعليل الأحكام الثرعية، تدور

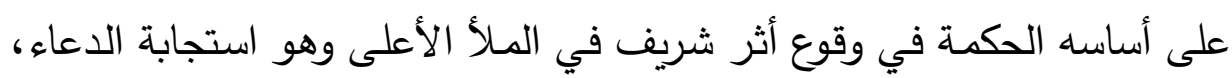
مدـا يكثـف عـن جانب آخر مـن حضـور قيمـة الوطن عنــ المحدثين، وأنهـ يستصحبون هذا المعنى الجليل في تفسير كلام النبوة والكثف عن أسبابه وعلله وحكمه.

**** *

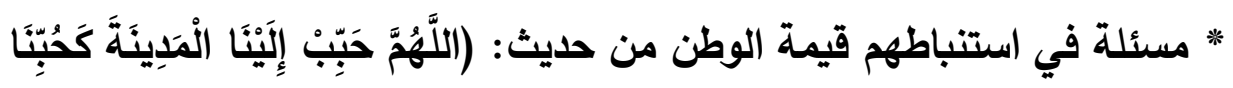

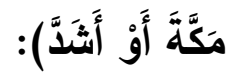
روى الإمام البخاري في صحيحه واللفظ له، ومسلم في صحيحه، وابن حبان

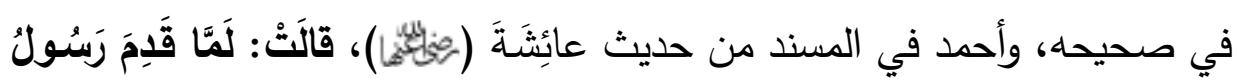

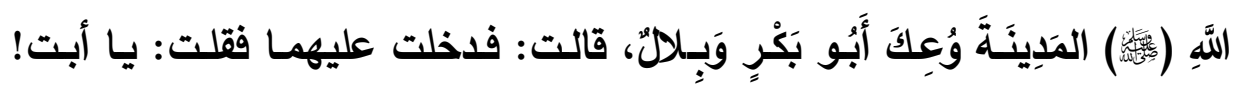

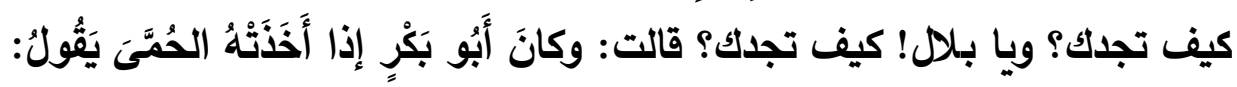

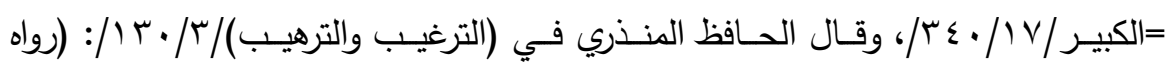

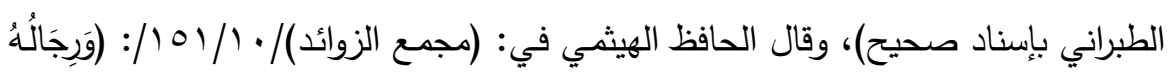

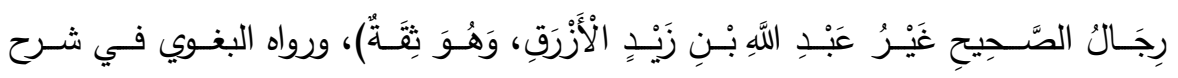

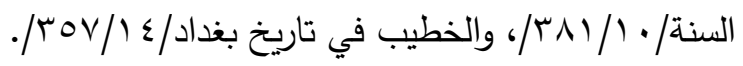

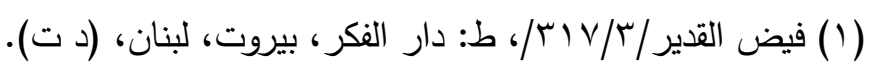




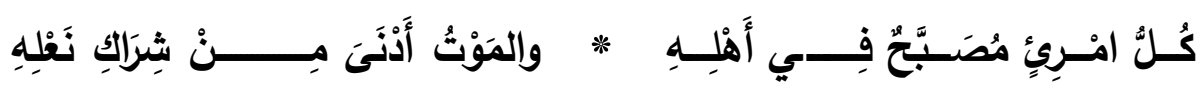
*****

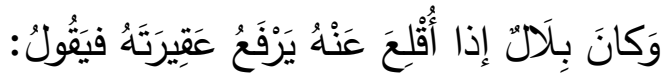

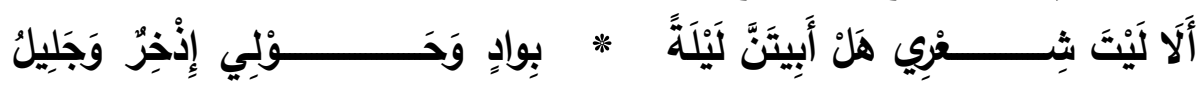

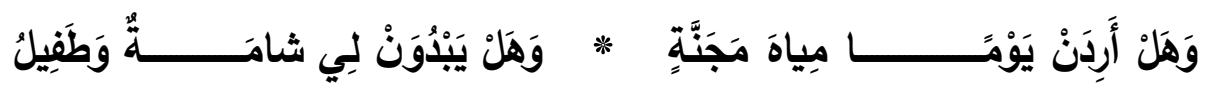

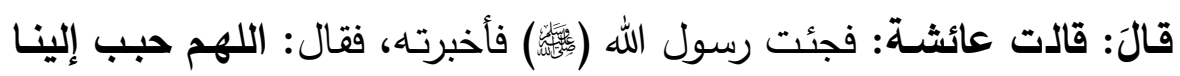
المدينـة كحبنـا مكـة أو أشـد، وصـحها، وبـارك لنـا في صـاعها ومـدها، وانقل حُمَّاها فاجعلها بالجحفة (1) وقد وقف شراح الحديث عند هذا الحديث الشريف وقفة تحليلية جليلة تبين استنباط معنى الوطن من هذا الحديث، قال ابن بطال في شرح صحيح البخاري: (وقال بعض العلماء: وأما حديث عائشة حين وُعك أبو بكر وبلال وإنشادهما في ذلك؛ فإن الله تعالى لما ابتلى نبيه بالهجرة وفراق الوطن، ابتلي أصحابه بما يكرهون من الأمراض التي تؤلمهم، فتكلم

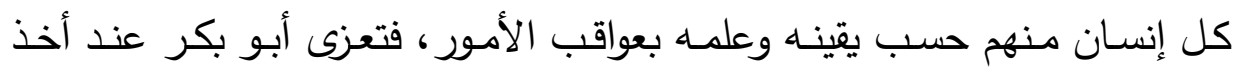

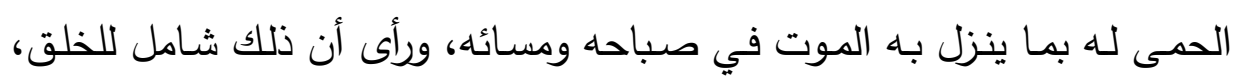
فلذلك قال: كل امرئ مصبح في أهله. يعني: تصبحه الآفات وتمسيه، وأما بـلال

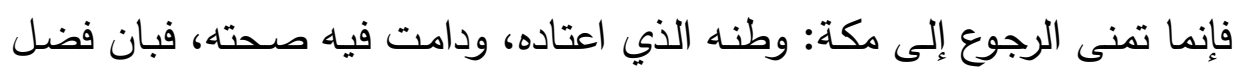
أبي بكر وعلمه بسرعة فناء الدنيا حتى مثل الموت بشراك نعله) (r).

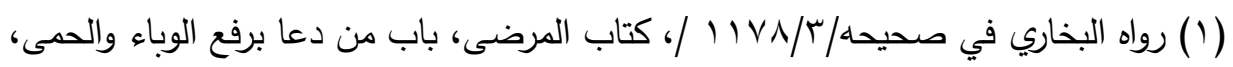

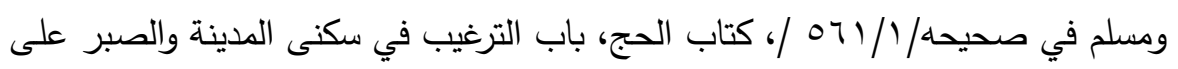

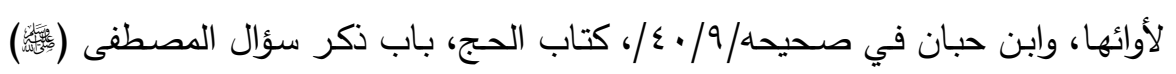

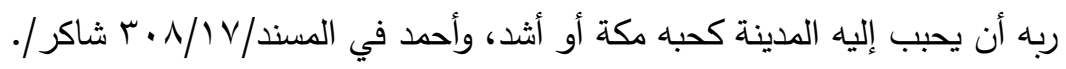

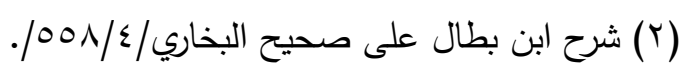


فهنا ظهرت فكرة الوطن في هدي النبوة وفي فهم الصحابة الكرام، ثم تفاضلت درجـات الصـحابة في درجات اليقين والنزوع إلى الآخرة، لكن أحوالهم جميعها أحوال فاضلة، استقوها من الهدي النبوي الثريف، والمتردد بين فإنـه دائر بين أنوارٍ وفهوم عوال، تليق بمقاماتهم العلية، وما كان يفيض عنهم من أحوال شريفة، كان مما ظهر فيها: معنى إجلال الوطن والحنين إليه. ********

\section{* مسئلة في استنباطهم قيمة الوطن من حديث: (ََفْلَةُ كَغَزَْةٍة).} روى الإمام الحاكم في مستدركه، والإمام أبو داود في سننه، والإمام أحمد في هي مسـنده، والإمـام الطحساوي في (شـرح مشكل الآثار)، والإمـام البغـوي في (شـرح

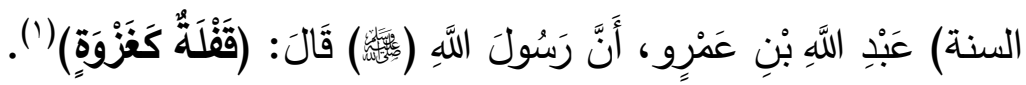
والقفلة بفتح القاف قال ابن الأثير: (المرة من الُقفول)(ب)، أي الرجوع.

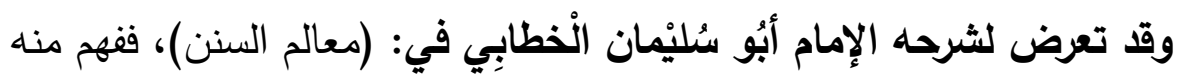

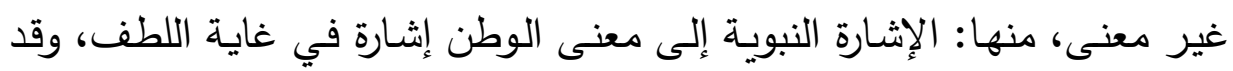

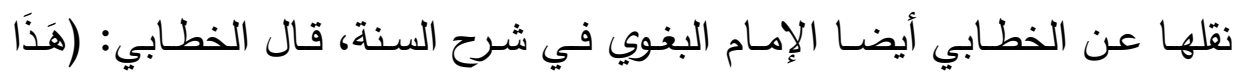

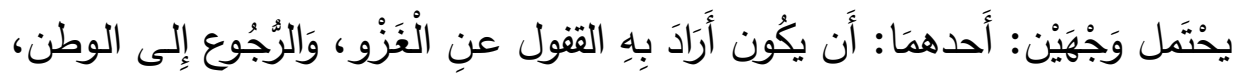

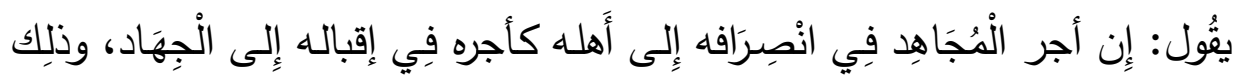

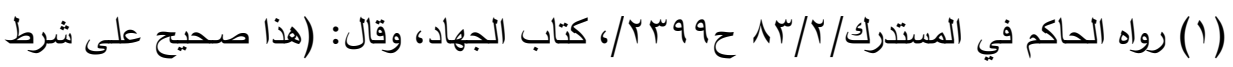

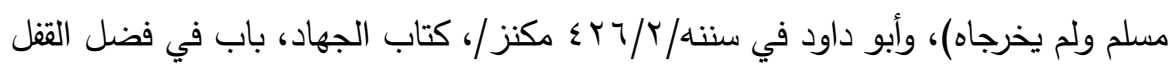

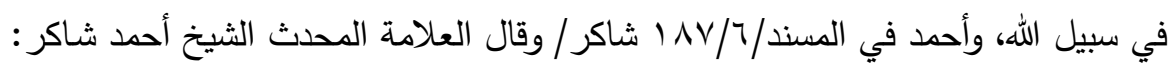

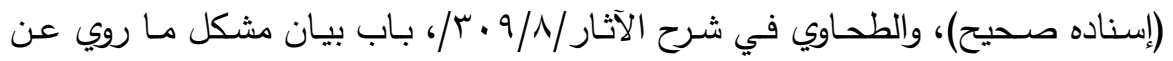

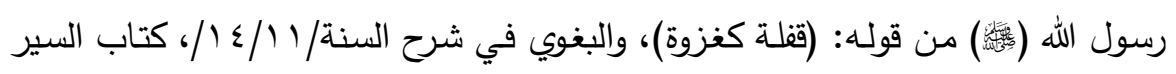

$$
\text { والجهاد، باب أخذ الجعل. }
$$




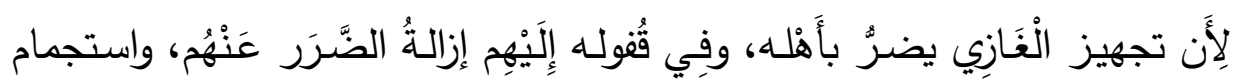

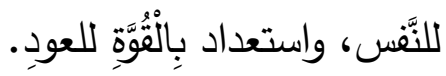

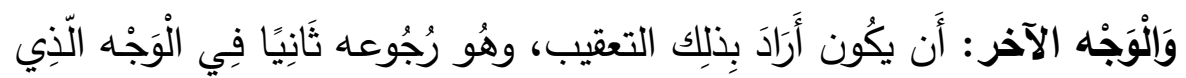

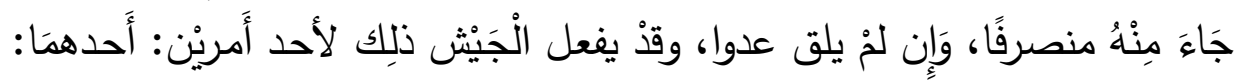

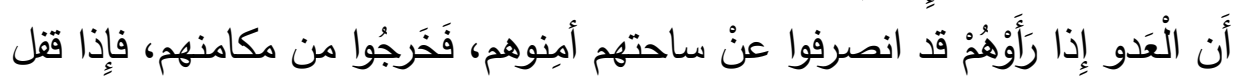

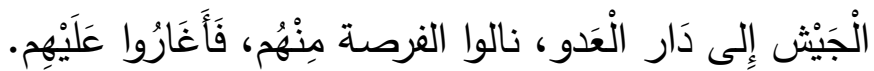

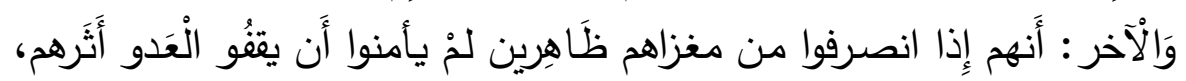

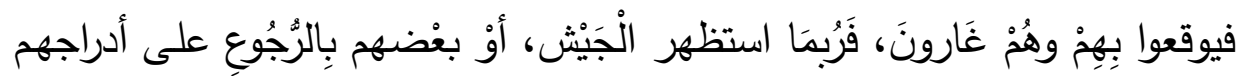

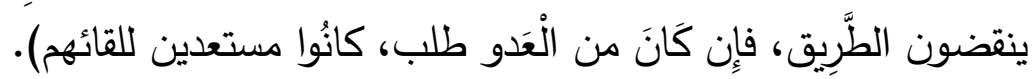

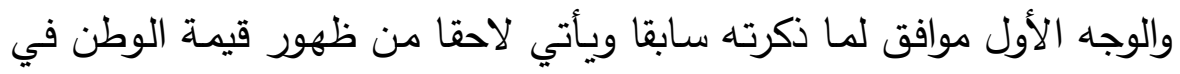
هدي النبوة، وأن تتزيل القفول منزلة الغزو فيه إثـارة إلى أنـه عند وقوع الأمـان

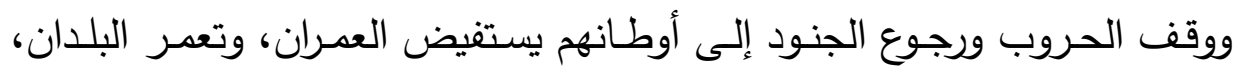

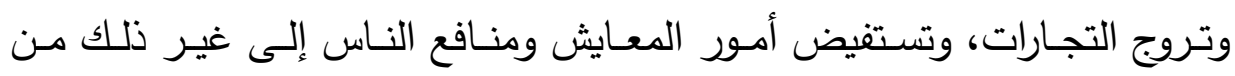
المقاصد الشرعية المعتبرة، ولا شك أن كل ذلك محقق لأمان الأوطان، ونابع من الن إنى حبها. *******

* مسئلة في استنباطهم قيمة الوطن من حديث: (بسم الله! تربـة أرضنا، بريقـة بعضنا، ليثفى به سقيمنا، بإذن ربنا).

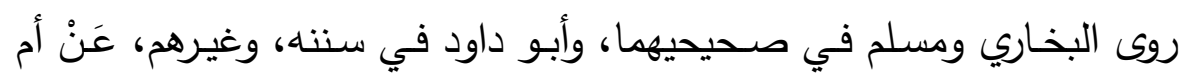

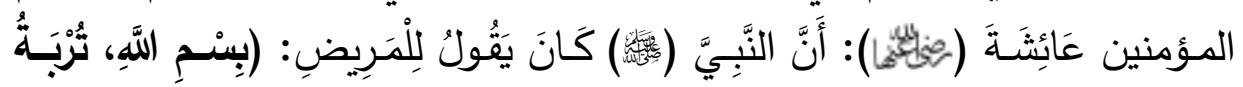

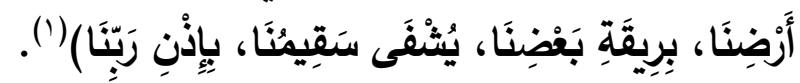

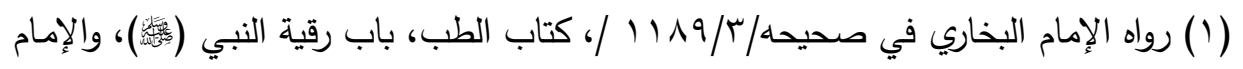

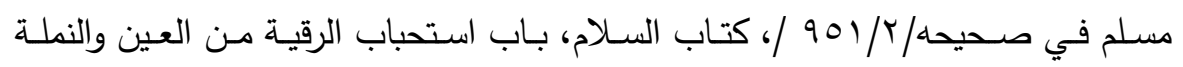

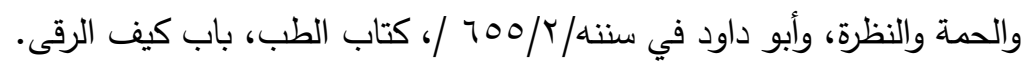




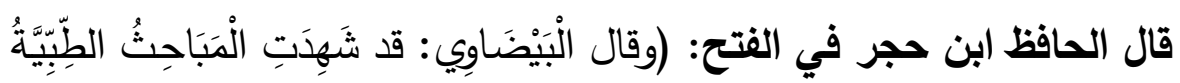

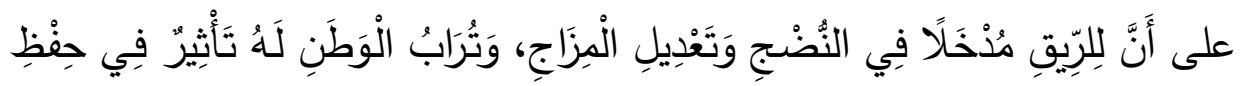

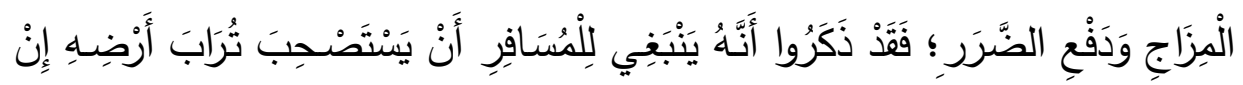

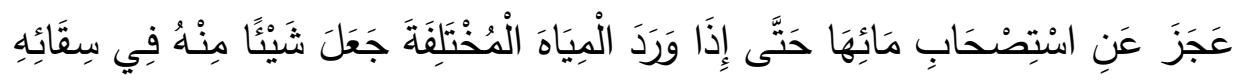

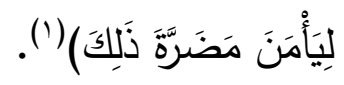
وقال الأستاذ الثيخ عبد الحميد بن باديس: (فقد علم الناس من قبل أربعة

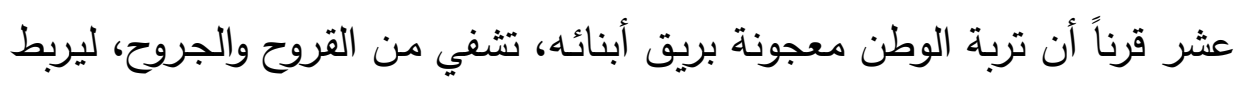

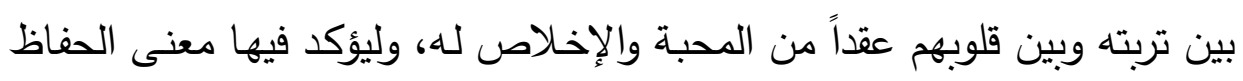

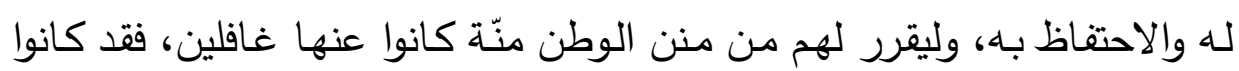
يعلمون من علم الفطرة أن تربة الوطن تغذي وتروي، فجاءهم من من لوطن علم النبوة أنها

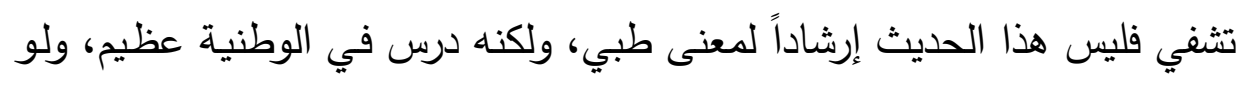

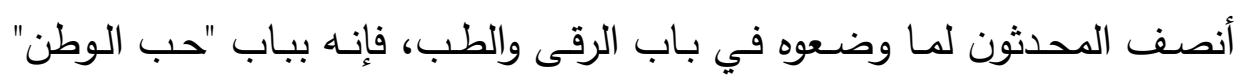

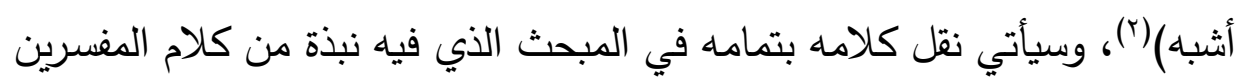
والفقهاء والزهاد عن الوطن. ******* $* *$

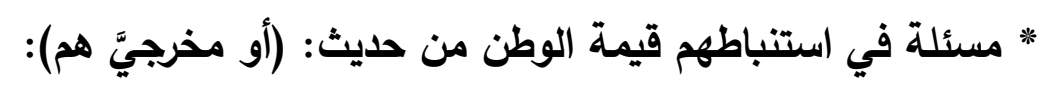

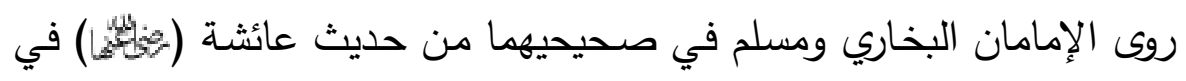
حديث بدء الوحي، فجاء فيه أنه صلى الله عليه لما انطلق مع خديجة إلى ورئل ورقية

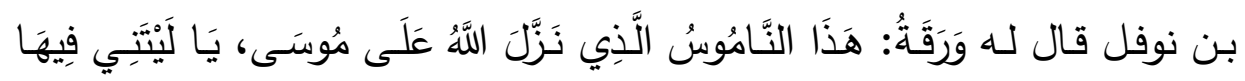

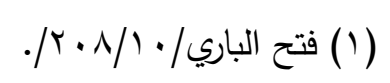

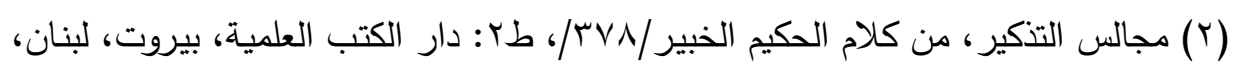

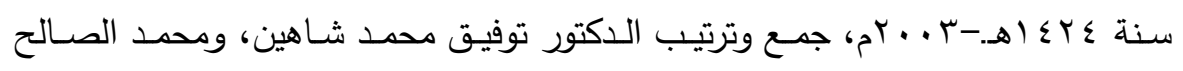




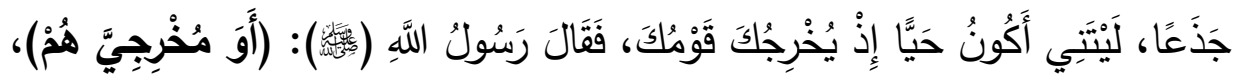

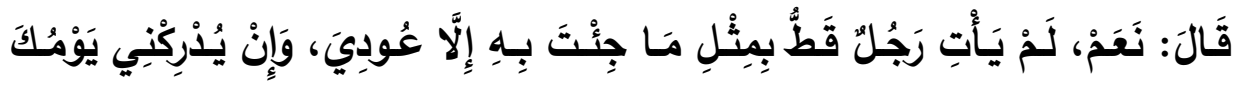

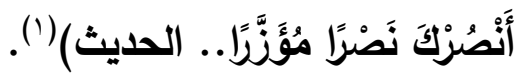
وقد استنبط الإمـام السهيلي في (الروض الأنف) من هذا الحديث الجليل

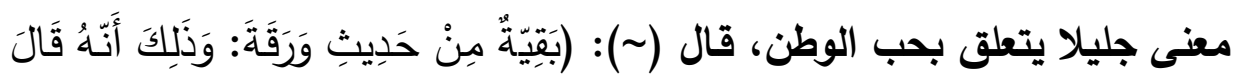

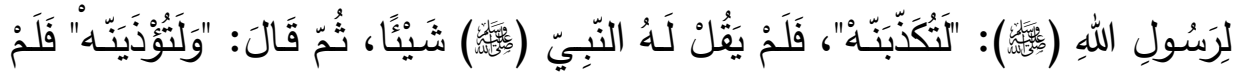

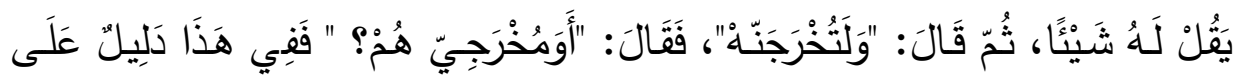

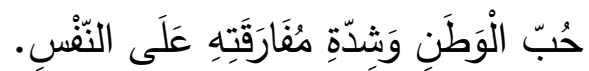

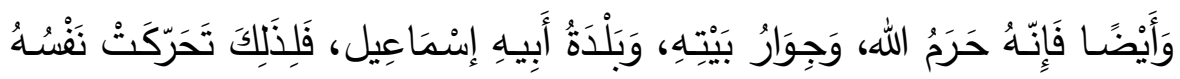

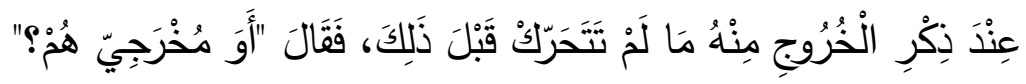

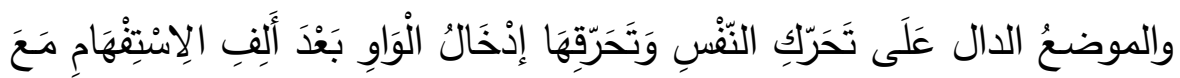

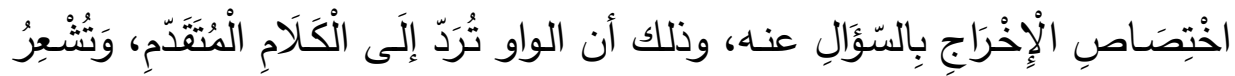

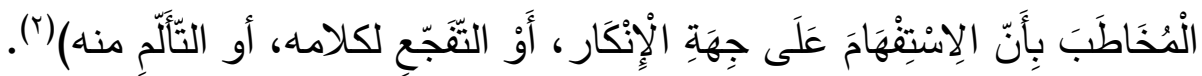
قال الحافظ أبو شامة في كتاب (المبعث): (قَالَ السُّهُيْلي: " وَفِي حَدِيث ورقة

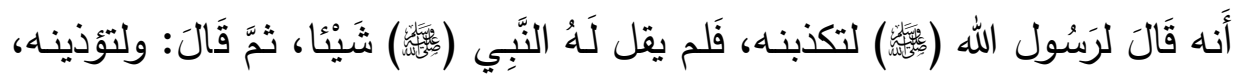

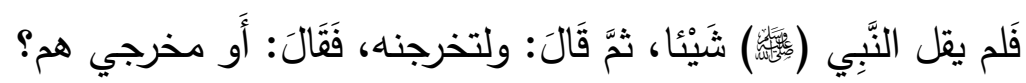

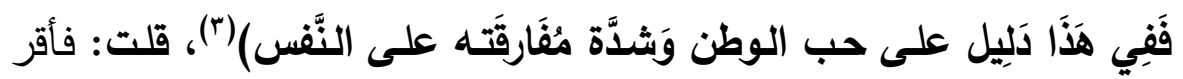
الحافظ أبو شامة هذا الاستنباط الحسن من السهيلي.

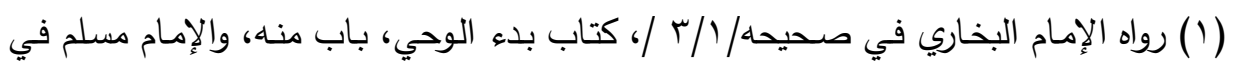

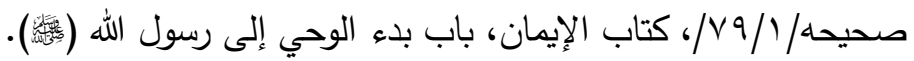

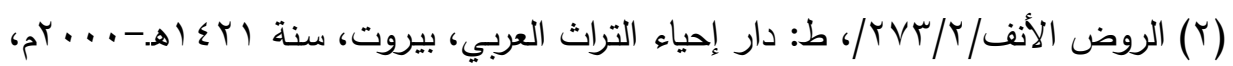
تحقيق عمر عبد السلام السلامي.

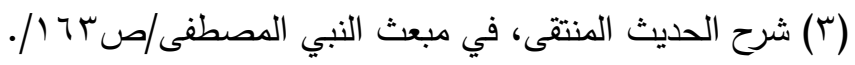


لكن نازع فيه شيخ الإسلام التقي السبكي، قال وللده الإمـام تاج الدين في:

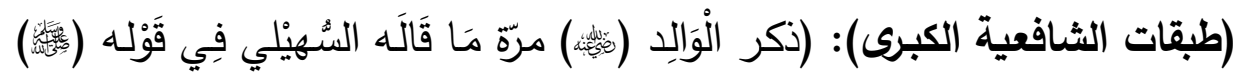

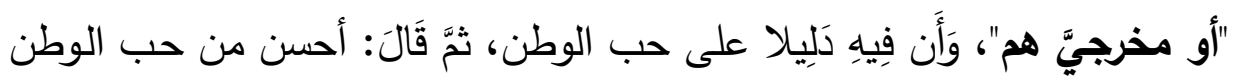

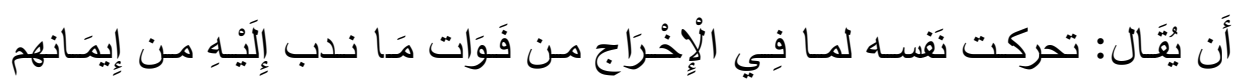

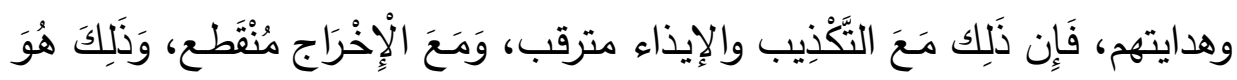

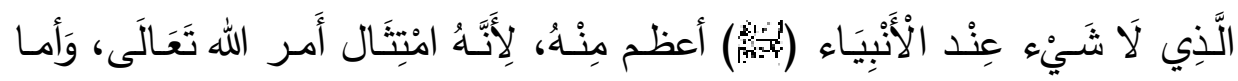

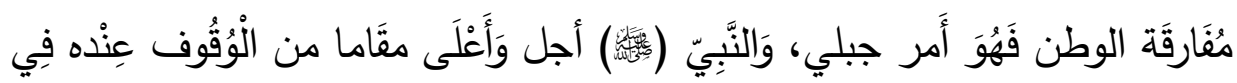
هَذَا الموطن الْعَظِيم)('). وأقول: هنا تعليق؛ حيث إن كلام الإمـام السبكي في غاية الحسن، والكثف عن حقائق المعاني التي تجري على الجنان النبوي الثريف، وهو رغم ذلك يمكن التعقيب عليه بما يجتمع به كلامه مع كلام الإمامين: السهيلي وأبي شامة، حيث

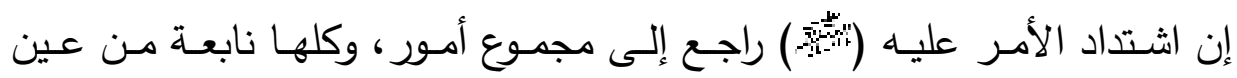
الوحي، منزهة عن الجبليات والبشريات المحضة التي تصان عنها بواطن الأنبياء المعصومة بالوحي؛ فمنها: فوات ما ندبه الله إليه وأقامه فيه من إيمانهم وهدايتهخ،

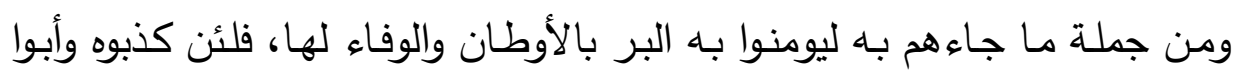
قبول هديه -وهذا راجع إليهم هم- فـلا يحملوه على الخروج الذي ينتقل بـه عن وطنه، فيرجع هذا إليه هو، في حال أن همم الأنبياء تأبى ترك البر ولو بحال الاضطرار ، مما أشار إليه صلوات الله وتسليماته عليه فيما رواه الترمذي من قوله:

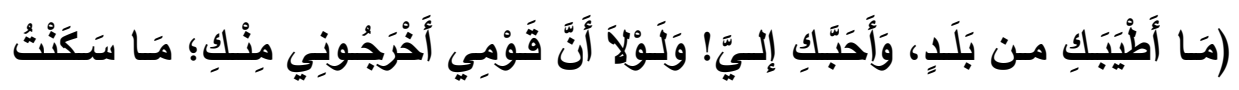

(1) طبقات الثـافعية الكبرى/ • / / / / طاء ط: دار إحياء الكتب العربية: فيصل عيسى البابي

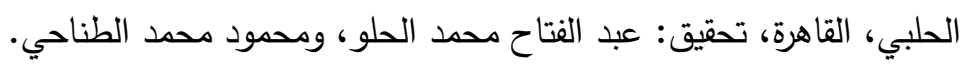


غَيْرَكِل)(')، وإنما اخترت لفظ الترمذي لأنهـ صلوات الله وسـلامه عليه أرجع جميع

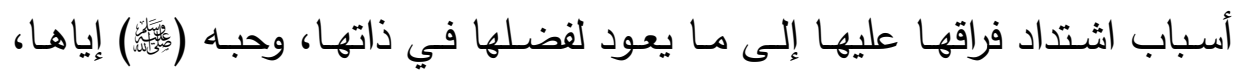
فتمض الكلام هنا للإثشارة إلى مـا اقترفوه من الحيلولة بينها وبين معنى شريف وهو كمال البر بهذا البلد الكريم المحبب إليه، فاشتد ذلك عليه صلوات الله تعالى مهي عليه، فيكون سبب الاشتـاد مركبا من مجموع الأمرين، وبـه يلتئم كلام الأئمـة،

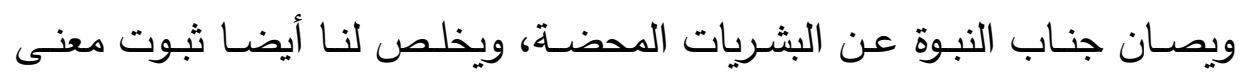
الوطن وأنه من جملة ما جاءت به مواريث النبوة.

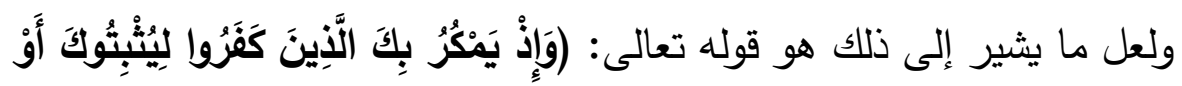

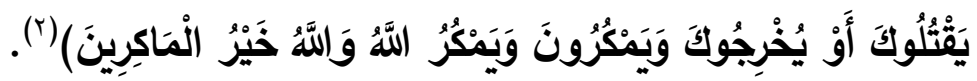
فاستعمل القرآن هنا معنى الإخراج الذي أشار إليه سيدنا ورقة، والذي سأل عنهـ سيدنا محمد (بُ إليها أولئك المعاندون من وراء مكرهم، وكلها تحول دون البلاغ عن الله، وتزيد إلى لى ذلك أن تعتدي على جنابه الثريف بالقتل، أو بالإخراج الذي يحول دون البلاغ ولاء

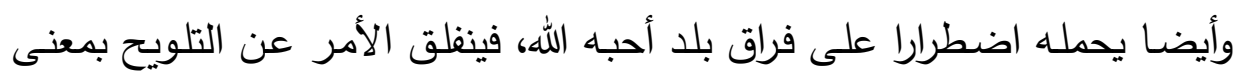
تعلق بواطن الأنبياء بأماكن وبقاع اختارها الله لهم بلدا، فأحبوها، ومن هنا جاءت الهات الهات

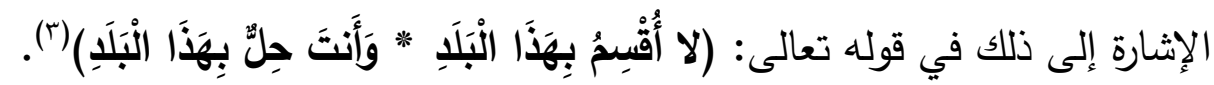
***** * *

( (1) رواه الترمذي في سننه/ /9 9 / /، كتاب المناقب، باب فضل مكة، وقال: هذا حديث حسن

$$
\begin{aligned}
& \text { صحيح غريب من هذا الوجه. }
\end{aligned}
$$

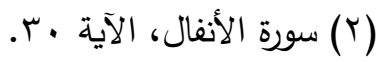

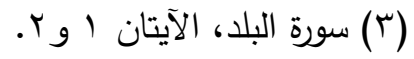


هذا وقد قال بعض الحكماء: الحنين إلى الوطن من رقة القلب، ورقة القلب من الرعاية، والرعاية من الرحمة، والرحمة من كرم الفطرة، وكرم الفطرة من طهارة

ولقد فطر الله تعالى الخلائق جميعا على الميل الفطري الحنيف اللطيف إلى أوطانهـا، وأودع سـبحانه في الفِطَر النقيـة مـن سـائر الموجـودات قرارا وسكونا وانشراحا إلى الوطن، حتى إن المتأمل ليجد ذلك في سائر أجناس الوجود، فالآساد والأشبال تأوي إلى عرينها، والإبـل تحن إلى أعطانها، والنمـل يحن إلى قراه، والطيور تهوي وتميل إلى وكناتها، والإنسان مجبول على مفطور على شدة الحنين إلى الوطن، وقد قال المحدث الجليل أبو الفرج ابن الجوزي ( ) في: (مثير الغرام الساكن): (والأوطان أبدًا محبوبة)('). وقد لاحظت العرب ذلك، وتفنتـ في تسمية أوطسان الكائنسات، حتى قال الحافظ ابن حجر في: (فتح الباري): (والعرب تفرق في الأوطان، فيقولون لمسكن

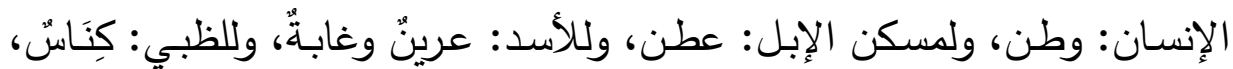

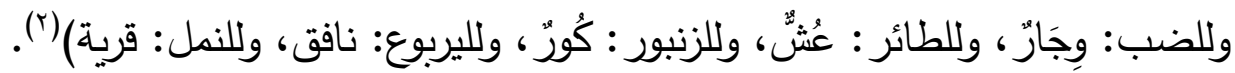

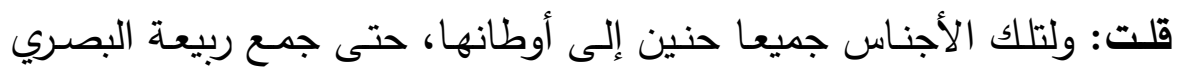
على سبيل المثال كتابا في: (حنين الإبل إلى الأوطان)، فكيف بالإنسان؟! فإذا كانت أجناس الوجود كلها من حولنا رغم أنها عجماء لا تفصح ولا تبين، قد تبين من ملاحظة طباعها وأحوالها شدة وفائها وحنينها إلى أوطانها، فالإنسان أولى بذلك منها، لما يمتاز به عنها من الكمالات الإنسانية، التي تجمله محلا لكل

(1) مثيـر الغـرام السـاكن، إلـى أشـرف الأمـاكن/صهوV/، ط: دار الحـديث، القـاهرة، ســـة 10

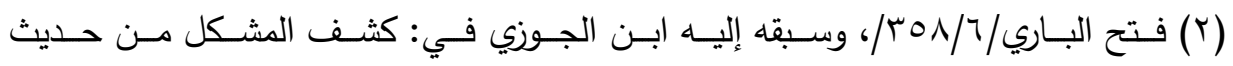

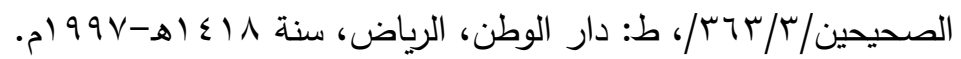




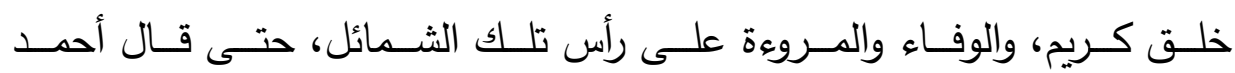
شوقي ( ): ( )

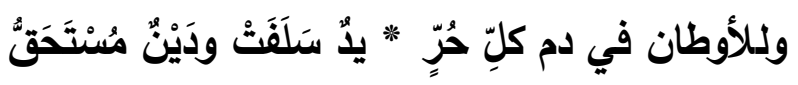

وأقول على غرار ذلك: الإنسان لكمال إنسانيته أولى بالوفاء للوطن، والقيام بمحبته وصيانته من سائر تلك الأجناس.

\section{Cत्र⿵冂人}




\section{|lill}

\section{في ذكر طائفة هن الامدثين برز مندهميم

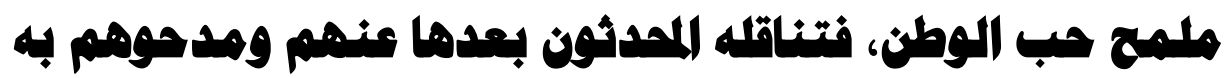

إذا كان المبحث السـابق تأصيلًا وتتظيرًا لقيمـة الوطن عند المحدثين، فمن الملائم أن نتبعه طائفة من تصرفاتهم وتطبيقاتهم العملية، التي ظهرت فيها منهم المواقف الدالة على تمكن هذا الخلق النبوي الكريم من طباعهم، فمن ذلك:

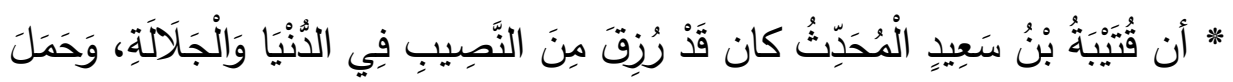

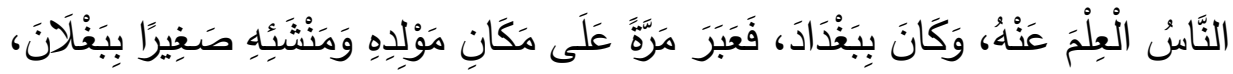

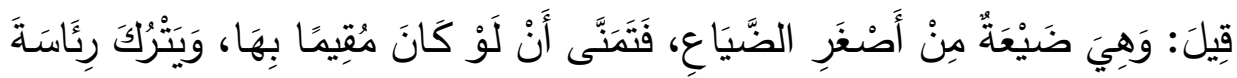

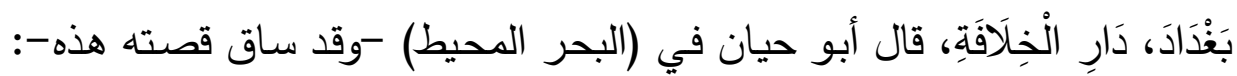

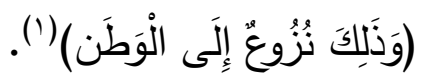
فانظر كيف وقف الإمام أبو حيان في تفسيره شارحا لهذا الموقف، ومبرزا لما يشتمل عليـه مـن معـان وقيم قد استقرت في وجدانـه، وأظهرتها المواقف، مدـا يكثف عن تأصيل قيمة الوطن عندهم، وأنهم فهموا هدي النبوة الشريف في هذا

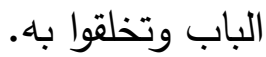

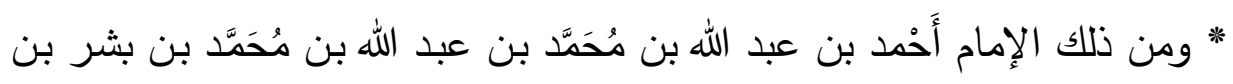

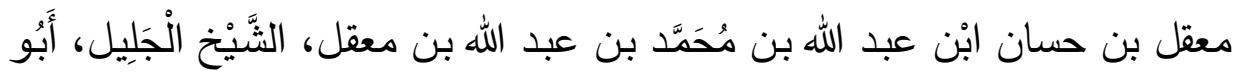

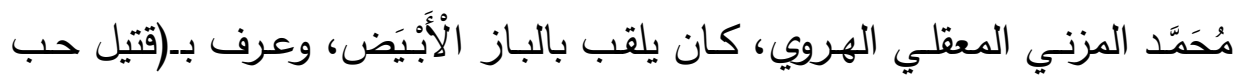

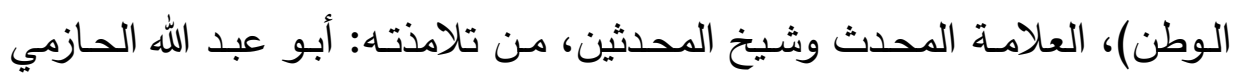
والحاكم النيسابوري. 
قَالَ الْحَاكِم: (كَانَ إِمَام أهل الْعلم وَالْوُجُوه وأولياء الَُْلْطَان بخراسـان في عصره

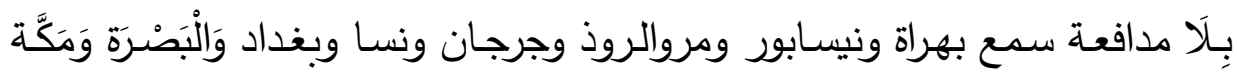
ومصر والأهواز).

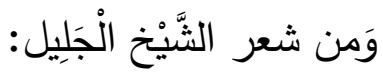

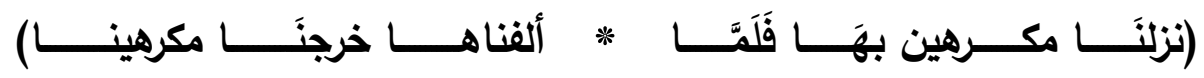

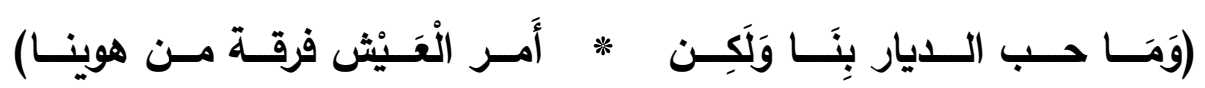

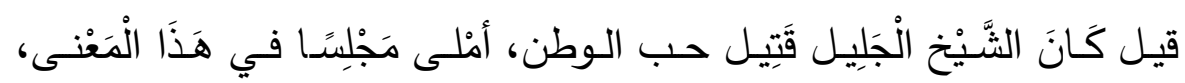
وَمرض عقبه، وَتوفى بعد جُمُعَة، في سَابِع عشر شهر رَمَضَان سنة سِتِّ وَخمسين وثلاثمائة (') فهذا مجلس إملاء حديثي جليل، في حب الوطن وافتدائه بالنفس، أملاه إمام محدث حـافظ، بـل شـيخ لمحدثي زمنـه، وكل ذلك يكثـف عـن جهود وأعمـال للمحدثين في تأصيل قيمـة الوطن، حتى سرت إلى انعقاد مجالس الإمـلاء لها، لتتطق المجالس الحديثيـة بهذه القيمـة العليـا، وتسـاق لهـا الأحاديث والمرويـات

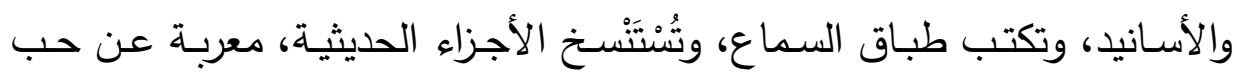
الوطن.

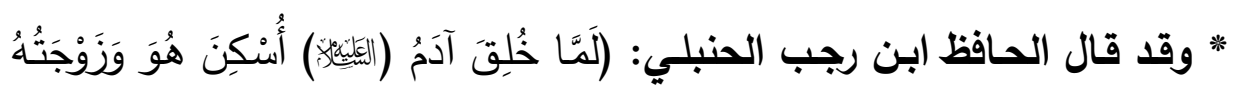

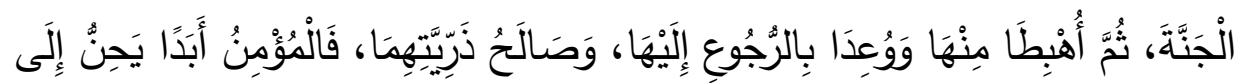

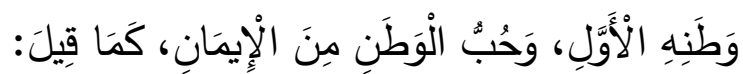

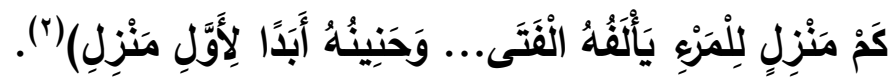

\section{(C)}

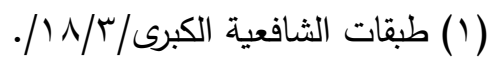

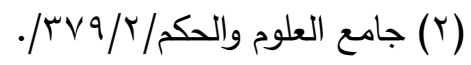




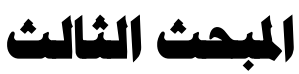

\section{في الكتب والإهفات التي أفردها الهفاظ ولامدثمن وفيرهم هن الوطن، وأكثر المشفين في هذا الباب هن المدثثين}

ولم يزل هذا المعنى يستفيض عند الأقدمين، وتتسع مـادة الكلام فيه،، حتى أفرد بالتآليف: * فألف الجـاحظ كتابه: (حب الوطن)، وقد طبع (')، وقد صدَّرت بهذا الكتاب النفيس لسبيين: الأول: أقدميته، وأنـه كان رائدا في هذا الباب، فلا أعلم أحدا قبله سبقه إلى التصنيف في هذه القضية. الثاني: أن له أثرًا بليغًا فمن جاء بعده من المفسرين والمحدثين، فقد تأثر به الإمام فخر الدين الرازي من المفسرين، كمـا سيأتي عند نقل كـلام الإمـام الرازي في لهـي المبحث الذي أورد فيه نبذة من كلام المفسرين والفقهاء والزهاد وبقية أرباب العلوم

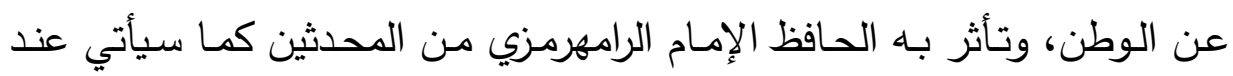
الكلام على كتابه (المناهل والأعطان، والحنين إلى الأوطان). ******

" ومنهم: القاضي أبو طاهر صالح بن جعفر بن عبد الوهاب الهاشمي الصالحي

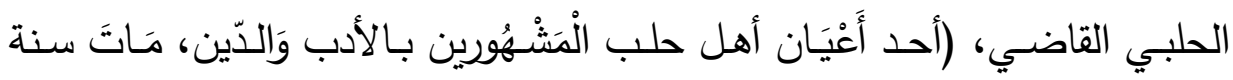

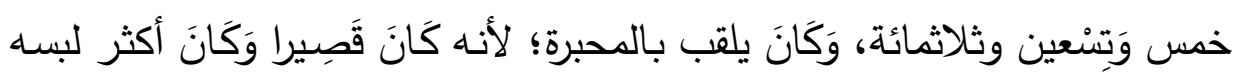
السوَاد)(؟)

$$
\begin{aligned}
& \text { (1) طبعـت رسـالة (الحنـين إلى الأوطـان) للجـاحظ، في دار الرائـــ العربـي، بيـروت، سـنة } \\
& \text { ماله }
\end{aligned}
$$

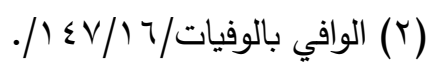


وقد صنف كتابًا جليلا في الحنين إلى الأوطان، ذكره الحافظ أبو القاسم ابن

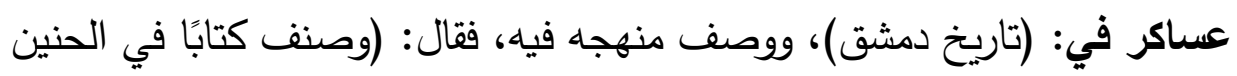

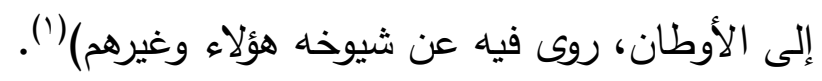
قلت: فهذا إذن كتاب على طريقة المحدثين وأهل الأثر ، يسوق فيه الأبه الأحاديث

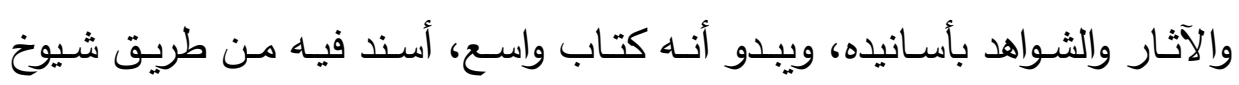

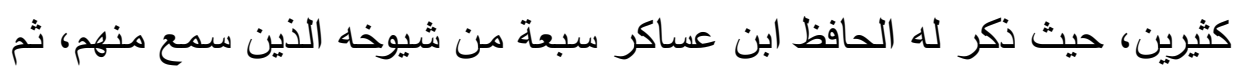

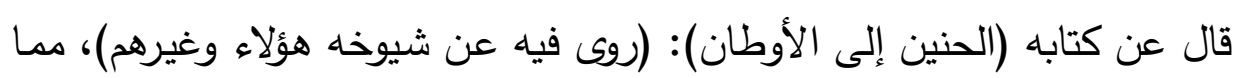
يشير إلى اتساع مادته، وتفننه في الرواية، وكثرة شيوخه.

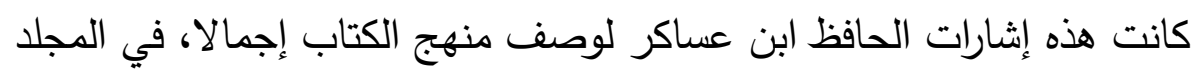

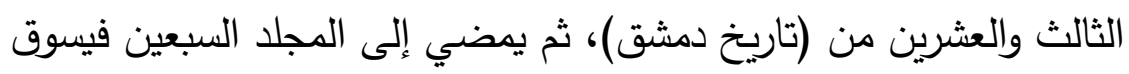

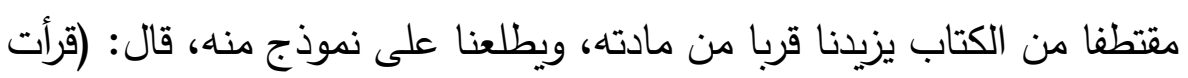

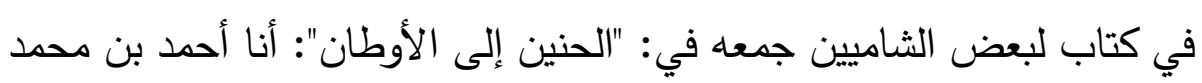

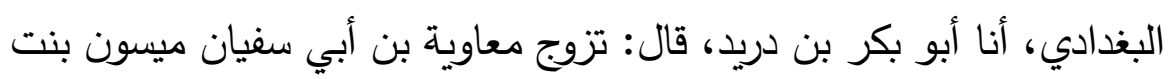

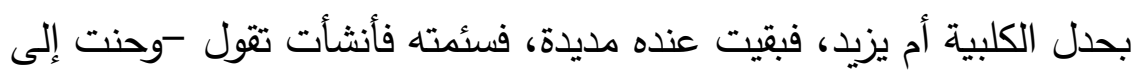

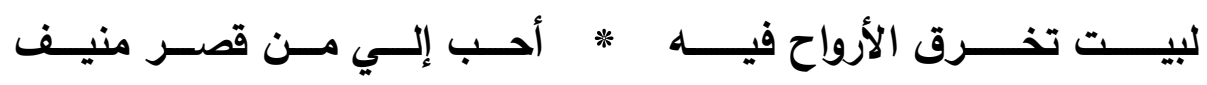

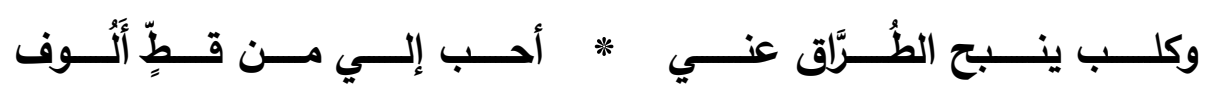

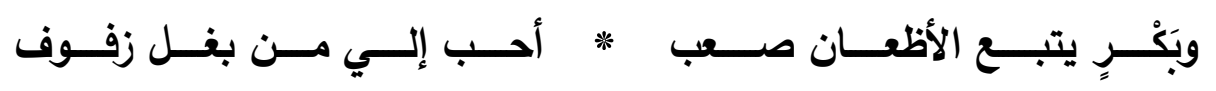

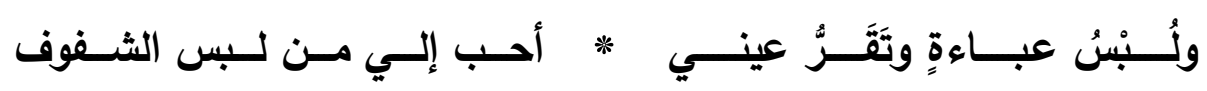

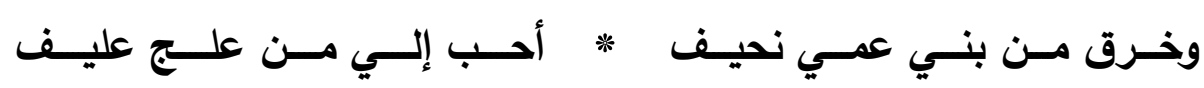

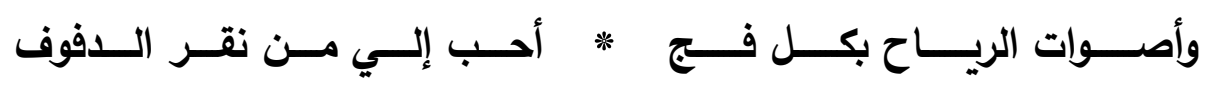

$$
\text { - } 24 \text { - تاريخ دمشق/Tro/rr/. }
$$


خثونة عيشتي في البدو أشهىى * إلى نفسـي مسن العسيش الطريـف

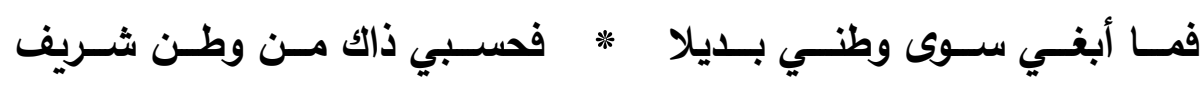

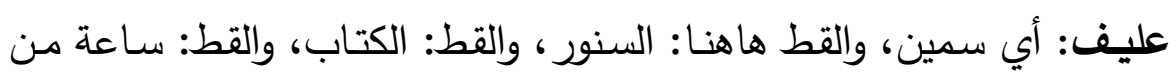

الليل) (')

وإن كان الحافظ ابن عساكر قد أبهـ هنـا اسم مؤلف الكتاب، فإن طريقـة

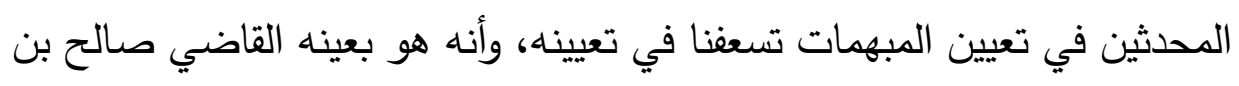

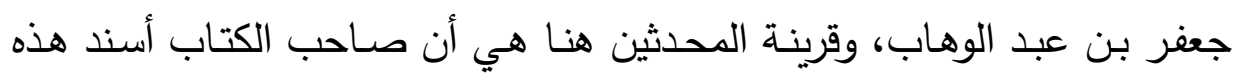

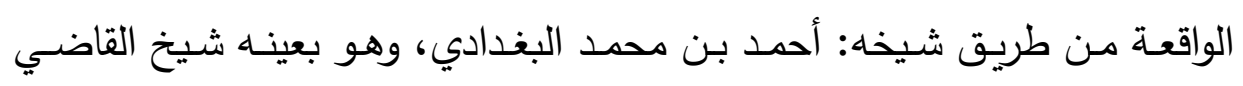

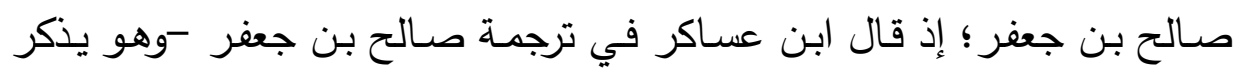

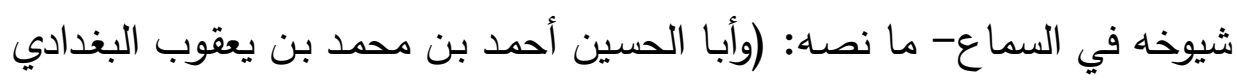
نزيل دمشق) (r). والحاصل أن هذا مقطع نفيس من كتاب (الحنين إلى الأوطـان) للقاضـي

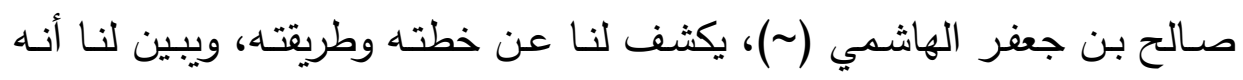

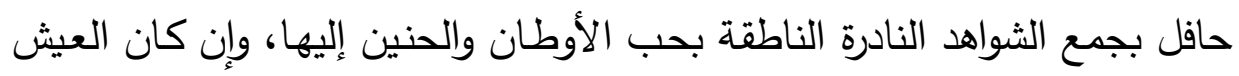
فيها خشنا، عسيرا، وأن هذا من أشرف الثمائل والأخلاق.

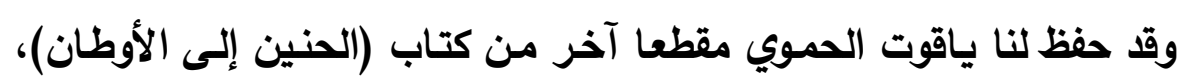

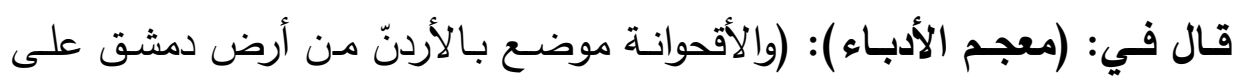

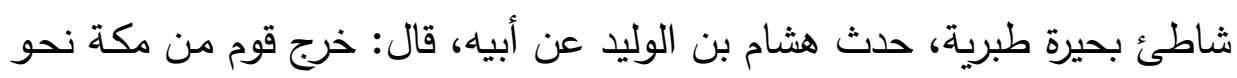

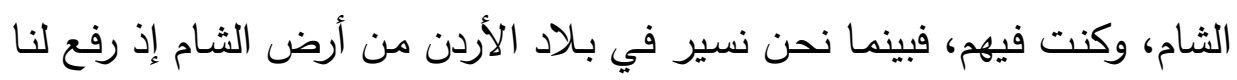

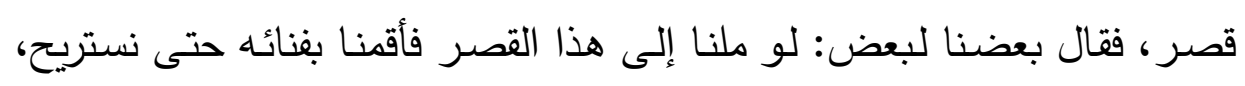

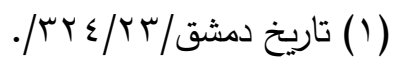

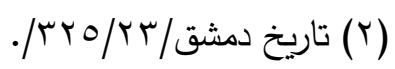


ففعلنـا، فبينمـا نحـن كذلك إذ انفتح بـاب القصـر وانفرج عـن امـرأة مثل الغزال العطشان، فقالت: من أي القبائل أنتم ومن أي البلاد؟ قلنا: نحن أضاميم من ههنا وهناك، فقالت: أفيكم من أهل مكة أحد؟ قلنا: نعم، فأنشأت تقول:

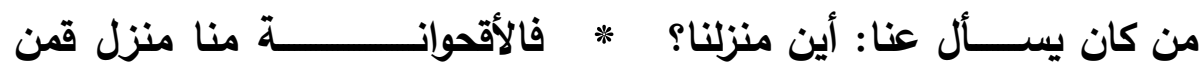
وإن قصري هذا مــــــــا به وطني * لكن بمكة أمســـى الأهل والوطن إذ نلبس العيش صـــفوا ما يكدّره * قول الوشاة، وما ينبو بــــه الزّمن

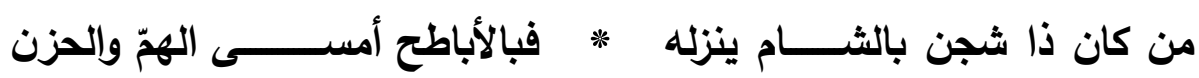
ثم شـهقت شهقة وخرّت مغشيّا عليها، فخرجت عجوز من القصر فنضـحت الماء على وجهها وجعلت تقول: في كل يوم لك مثل هذا مرّات، تالله للموت خير لك من الحياة.

فقلنا: أيتّها العجوز ما قصّتها؟ فقالت: كانت لرجل من أهل مكة فباعها، فهي لا تزال تنزع إليه حنينا وشوقا.

قال القاضي الثريف أبو طاهر الحلبي صاحب كتاب "الحنين إلى الأوطان" -عند فراغه من هذا الخبر -: والأقحوانة ضيعة على شاطئ بحيرة طبرية، وقمن الهن

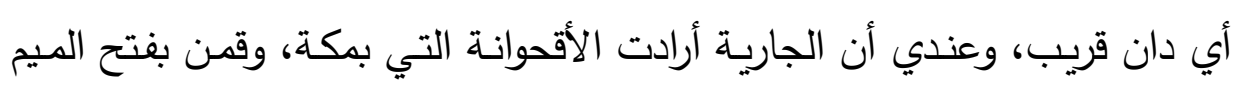
أي خليق، تعني أن ذلك المنزل جدير أن أكون فيه. ثم عقب ياقوت بقوله: (ولم أر في كتب اللغة القمن بمعنى القرب، إنما قال

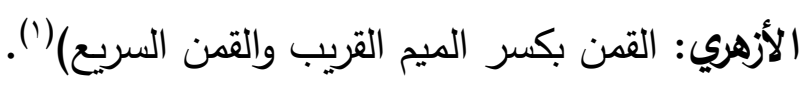


فعقب عليه المحدث الحافظ الكبير السيد محمد مرتضس الزبيدي في (تاج

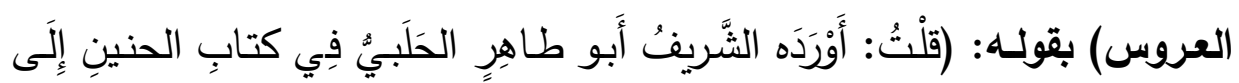

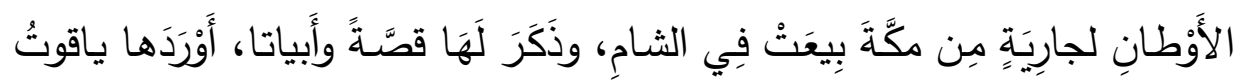

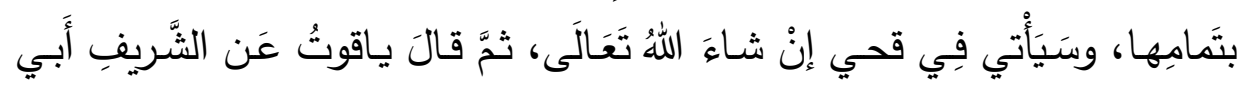

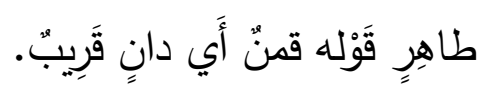

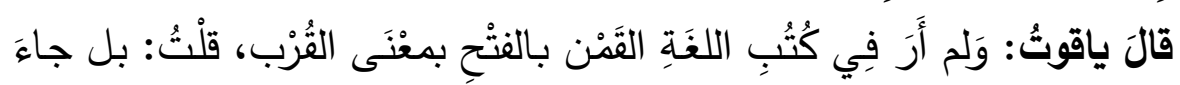

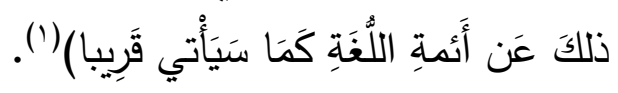
قلت: ومن هذا يظهر عناية المحدث القاضي أبي طاهر الحلبي في كتابه بضبط اللغـة، والتدقيق في ذلك، فنقل عنـه ياقوت هذا التحرير اللغوي النفيس، ونقل عنه الحافظ ابن عساكر ضبطه للفظ القط وأنه مشترك لغوي. *******

* ومنهم الإمام الحافظ أبو سعد عبد الكريم بن محمد السمعاني، وقد ألف هذا

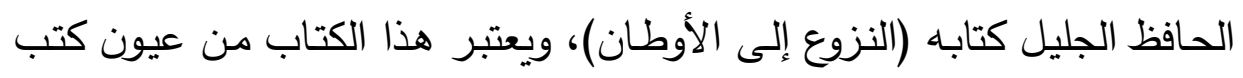
الحفاظ والمحدثين في الإبانة عن قيمة الوطن. وقد كان تأليفه الحافظ أبي سعد السمعاني له قبل تأليف (كتاب الأنساب)،

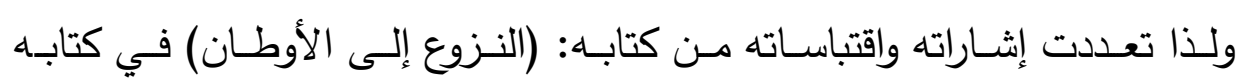
(الأنساب)

فقال مثلا عند كلامه عن البصري: (هذه النسبة إلى البصرة، وشهرتها أغنتي

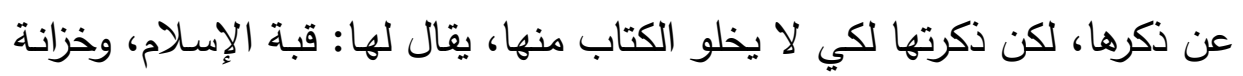

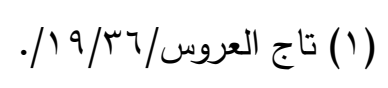


العرب، وقد ذكرت نبذا من فضـائلها في كتاب: "الإسفار، عن الأسفار"، وفي

كتاب: "النزوع إلى الأوطان، والنزاع إلى الإخوان")(').

وقال مثلا: (وقد ذكرت قصته وسبب بنائه في كتاب النزوع إلى الأوطان) (؟).

وقـال: (قـال الـارقطني: وأمـا بـوان فهـو شـعب يعرف بشـعب بـوّان، وفيـه يقول الشاعر : (1)

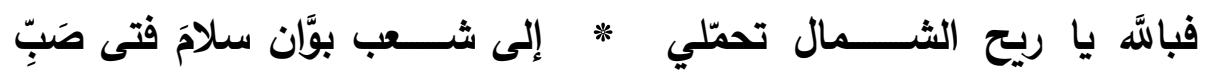
في أبيات طويلة، وفيها:

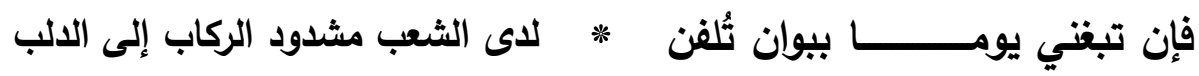
قلت: وقد ذكرت هذه الأبيات في: "النزوع الى الأوطان")(r).

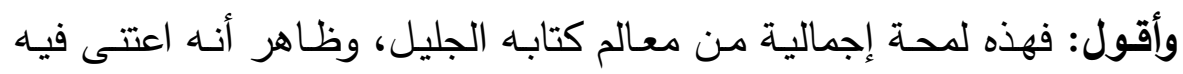
بإيراد كل ما وصل إليه اطلاعه الواسع من شواهد حب الأوطان وبرها وإجلالها، ولاشك أنه صدَّر ذلك بشواهد الآيات والأحاديث، وأنه وفَّى الصنعة الحديثية حقها،

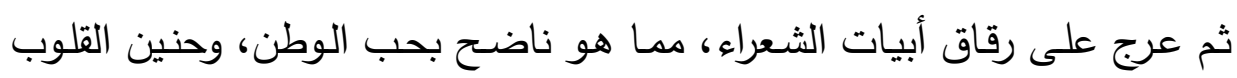
إليه، وإن من الثعر لحكمة. وقـال أيضـا: (بلدة هراة، وهي إحدى بـلاد خراسـان، وقد ذكرت فضـائلها في

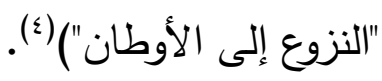

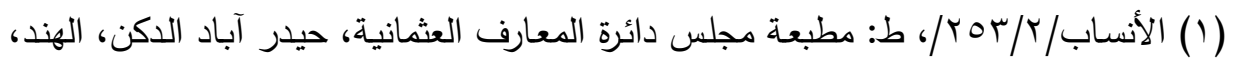

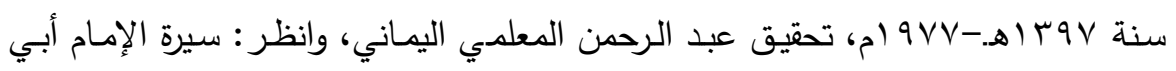

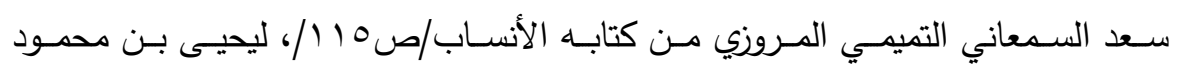

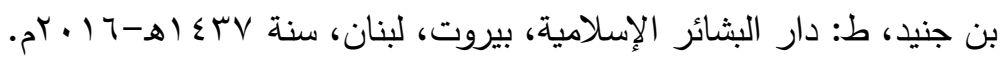

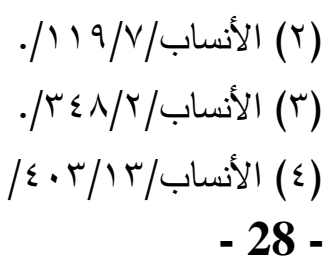


وهنا إثارة أخرى إلى أنه اعتى في كتاب (الذزوع إلى الأوطان بذكر فضـائل

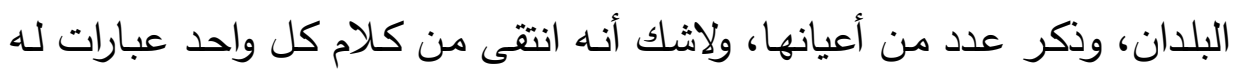
في نزوعه إلى وطنه، وحنينه إليه.

***** $*$ *

* وللحافظ المتقن الإمام أبي محمد الحسن بن عبد الرحمن بن خلاد الرامهرمزي كتاب: (المناهل والأعطان، والحنين إلى الأوطان). وقد احتفظ لنا ابن النديم في كتابه النفيس: (الفهرست) بأخبار نادرة عن الأن إنان

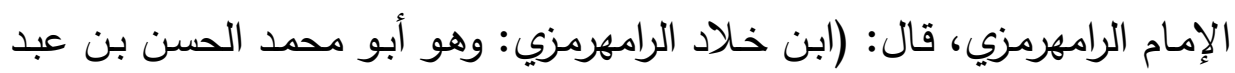

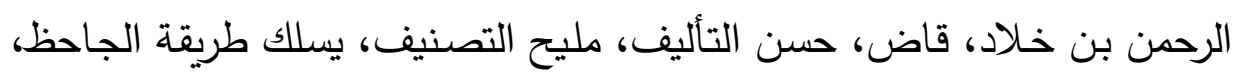
قال لي ابن سرار الكاتب: إنه شاعر ، وقد كان سمع الحديث ورواه.

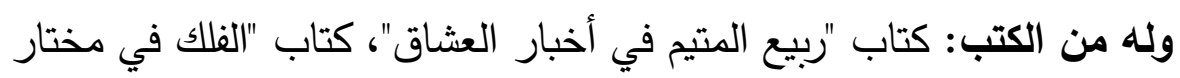

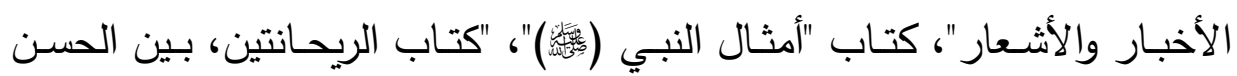

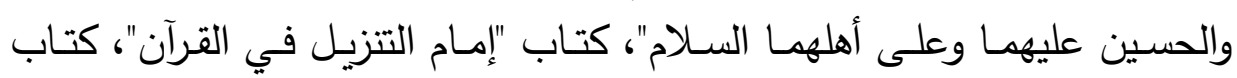
"النـوادر والثـوارد"، كتاب "أدب النـاطق"، كتاب "الرثاء والتعـازي"، كتاب "رسـالة

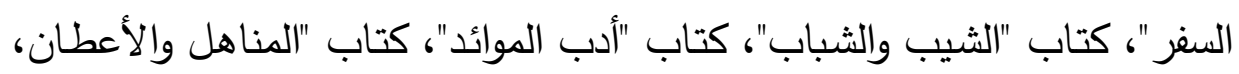

$$
\text { والحنين إلى الأوطان")(') }
$$

فأفاد هنـا إفـادات نفيسـة عن شيخ المطان المحثين الحافظ الرامهرمزي، منها تأثره بالجاحظ، وأنه يسلك مسلكه في تصانيفه، وهذا يفسر العبارة العذبة الجزلة الآسرة في كتابه (المحدث الفاصل). وإذا كان العلامة المحدث الثيخ عبد الفتاح أبو غدة يجعل من جملة محاسن مقدمة الإمـام ابن الصـلاح أنها تصوغ المصطلح بقلم أديب، فكيف ببيان الإمـام الرامهرمزي الذي يجري على سنن الجاحظ في التعبير .

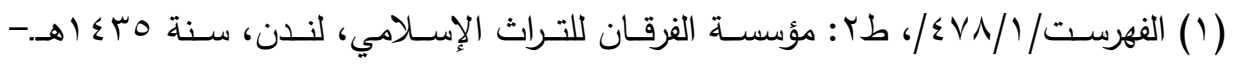

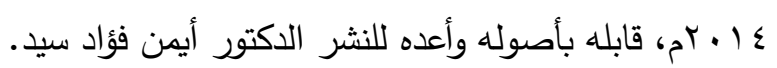


وتبقى من وراء ذلك كتب أخرى أفردها العلماء والباحثون لإبراز قيمة الوطن،

منها:

* كتاب لأبي حاتم سهل بن محمد السجستاني المتوفى بالبصرة سنة هـ بهـ. وقد سماه: (الثوق إلى الأوطان)، نسبه إليه العلامة الجمال القفطي في: (إنباه

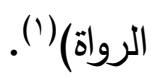

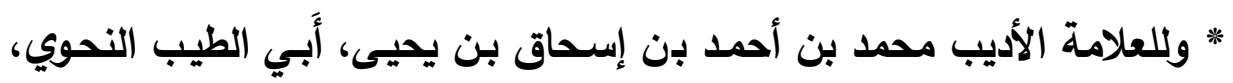
المعروف بابن الوشاء الأعرابي كتاب: (الحنين إلى الأوطان) (†).

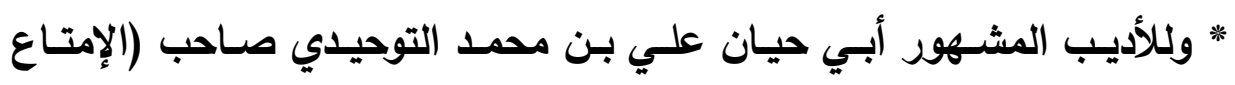
والمؤانسة) كتاب: (الحنين إلى الأوطان) (־). ثم هناك كتب أخرى لعدد من المعاصرين، منها:

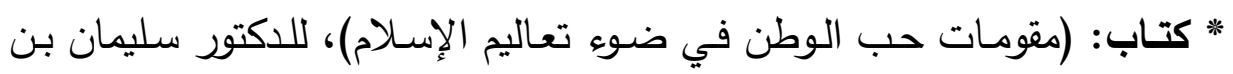

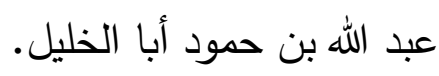
* وكتاب: (حب الوطن من منظور شرعي)، للدكتور زيد بن عبد الكريم الزيد، أهداني مؤلفه نسخة منه. (ابت الوطن من وكن

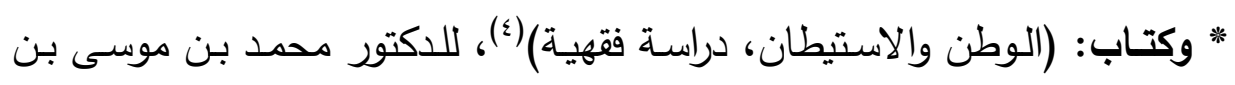

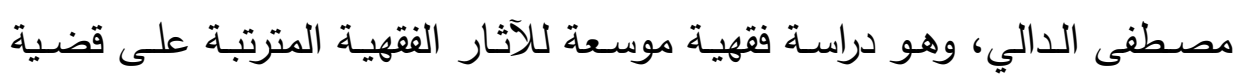

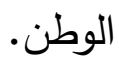

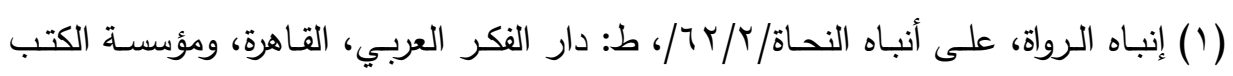

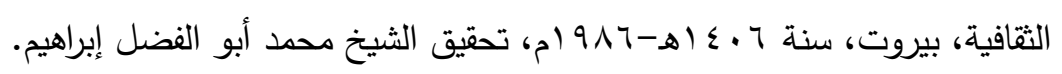

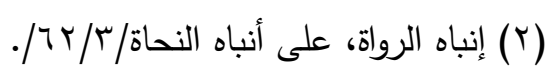

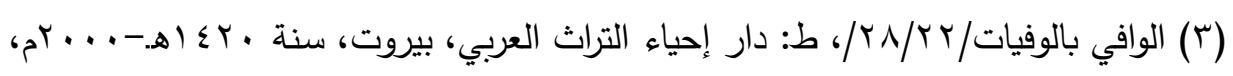

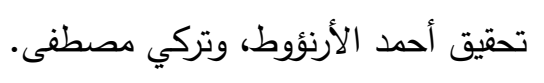

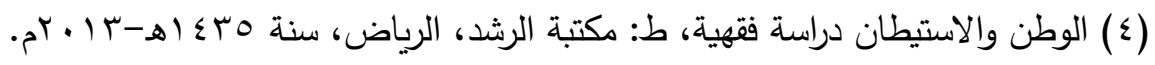




\section{المبمث الرابع}

\section{في نبذة من كلام المشرين والفقهاء والزهاد وبقية أرباب العلوم عن الوطن}

لمحة من حب الوطن في القرآن الكريم وكلام المفسرين:

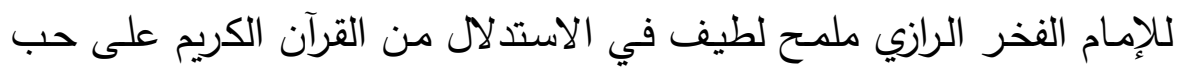
الوطن، وأنه داع فطري شديد العمق في النفس؛ أثار إليه في: (التفسير الكبير )

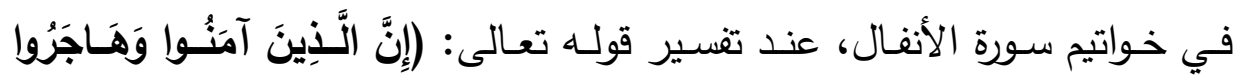

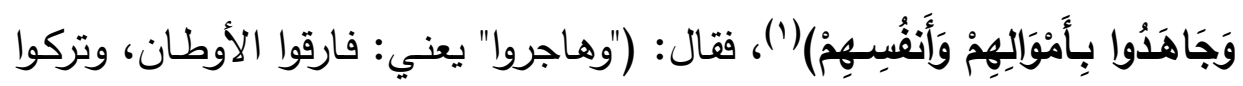

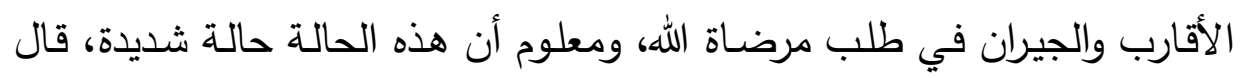

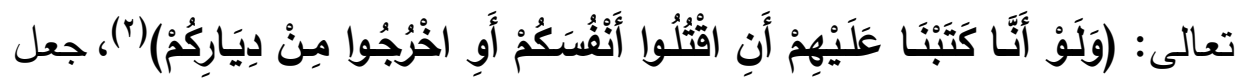
مفارقة الأوطان معادلة لقتل النفس) ().

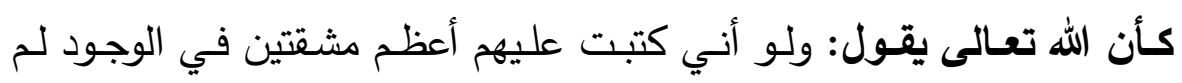

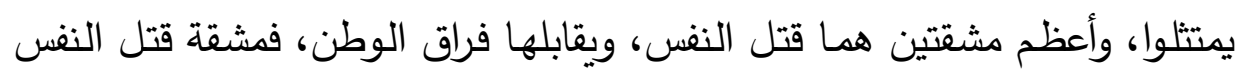
في كفة، ويوازيها ويساويها تماما فراق الوطن.

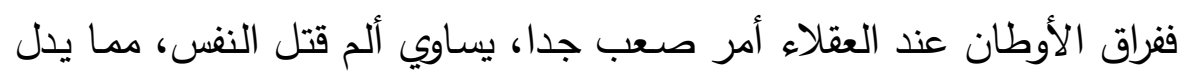
على أن التعلق بالوطن وحبه أمر عميق في النفس، وأنه محمود.

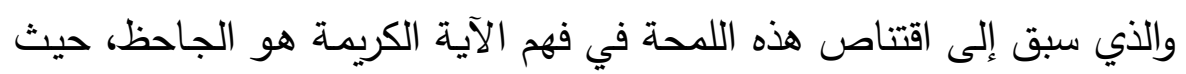

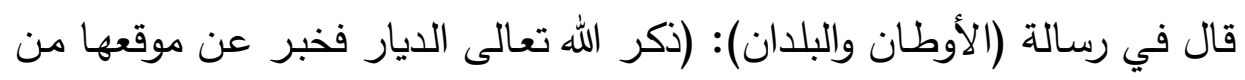

$$
\text { (Y) سورة الأنفال، الآية YY. (Y) }
$$

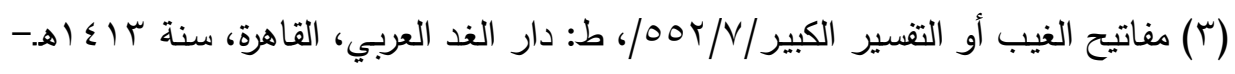




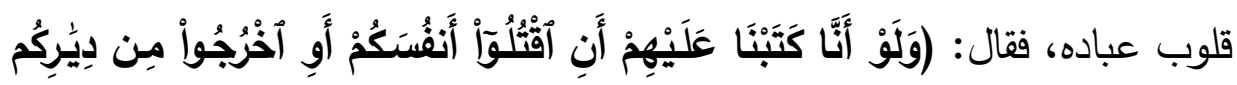

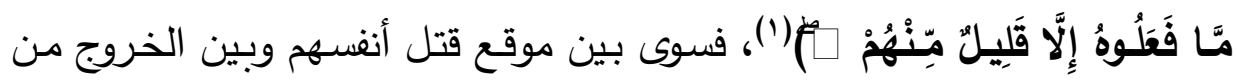

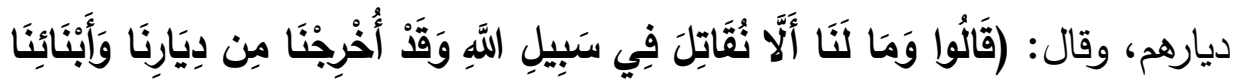

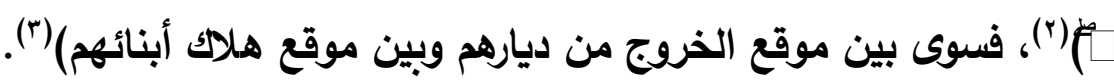

" ومن استنباطات المفسرين أيضـا قول الإمسام ابن الجوزي أيضـا في (تذكرة

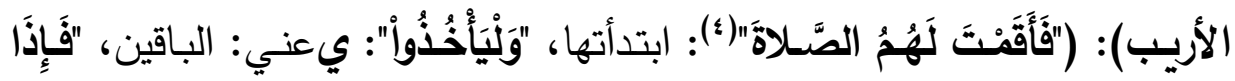

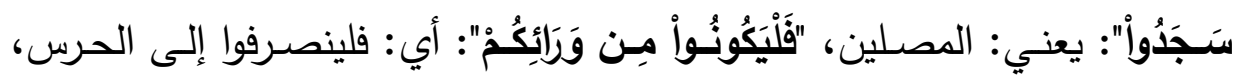

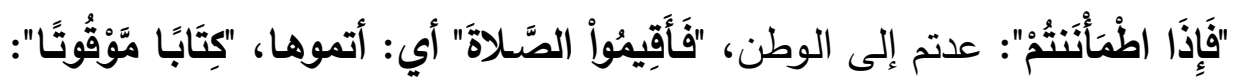
أي مفروضًا)(ن) وهنا فقد لمح الإمام ابن الجوزي بشفوف نظره ودقة فهمه في السياق القرآني أن الاطمئنان المعبر عنه في الذكر الحكيم إثارة إلى رجوعهم إلى أوطانهم، حيث خرج كل منهم من حال الخوف والترقب والفزع، وعاد إلى وطنه وأهله، ورفع الجرح عنه، وسكن خاطره واستقر ، فإذا بالقرآن الكريم يشير إلى ما يشتمل عليه الوطن من تلك المعاني الجليلة.

(1) (1) سورة النساء، الآية 7 (1)

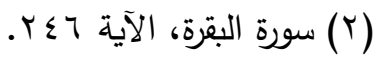

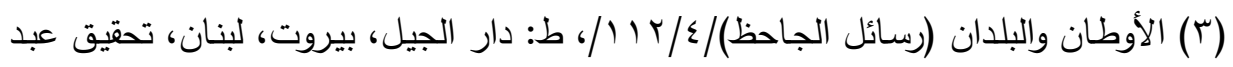

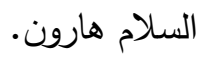

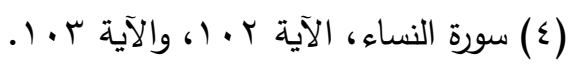

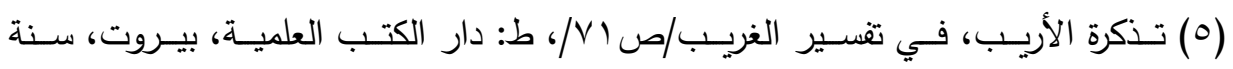

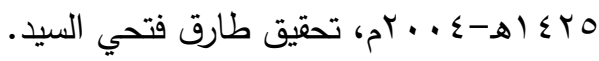


وقد تعرض ( ) في: (زاد المسير) إلى ذلك، فبسط أقوال المفسرين فقال: (قوله تعالى: "فَاذْكُرُوا اللََّ"('): في هذا الذِّكر قولان: أحدهما: أنه الذكر لله في غير الصلاة، وهذا قول ابن عباس، والجمهور قالوا: وهو التسبيح، والتكبير ، والدعاء،

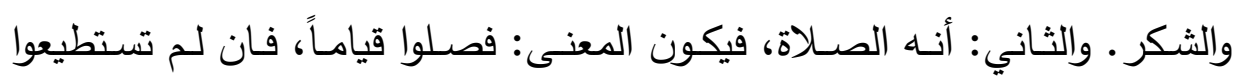
فقعوداً، فان لم تستطيعوا فعلى جنوبكم، هذا قول ابن مسعود. وفي المراد بالطمأنينة قولان: أحدهما: أنه الرجوع إلى الوطن عن السفر، وهو

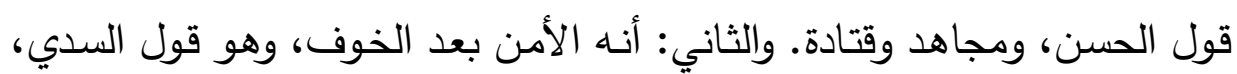
والزجاج، وأبي سليمان الدمشقي)(r). وهنـا وقفـة مهمـة؛ حيث إن الإمـام ابن الجهوزي ( ) : تباينت عنده أغراض التأليف، فلما أن كان كتابه (زاد المسير) قائما على حكاية أقوال المفسرين على الإهـ

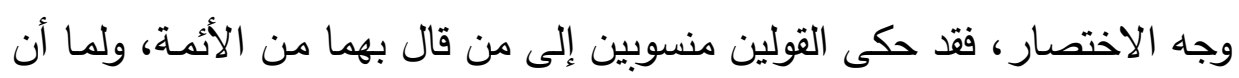
كان كتابه (تذكرة الأريب) مختصـرا قائمسا على الاختيار والانتقاء من بين أقوال المفسرين فقد اقتصر هو على تفسير الآية بمعنى الوطن، وارتضساه، وما حكى سواه، بل أورده مجزوما به، مما يدل على أن هذا هو اختياره وترجيحه. ***** * *

* ومن استتباطات المفسرين أيضًا: قول العلامـة المـلا علي القاري في: (مرقاة المفاتيح): (ومفارقة الأوطان المألوفة هي أشد البلاء، ومن ثم فُسِّرَ قوله تعالى:

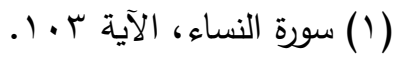

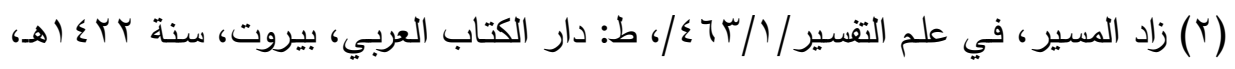
تحقيق عبد الرزاق المهدي. 


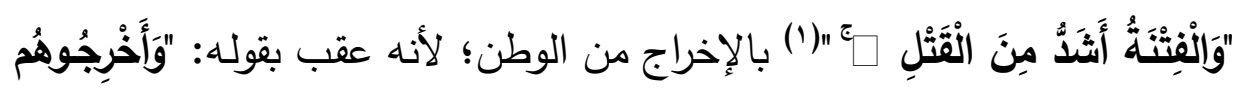

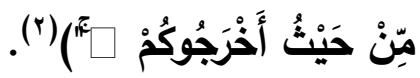

ومن ثم فإن كل آية تظهر فضل الهجرة فإنها راجعة إلى هذا الأصل، والذي هو شدة الصبر ومغالبة النفس، على فراق الأوطان المحبوبـة، إيثار لمعنى من هن إنى المعاني الشريفة، فكم لهذا المعنى من قدر، حتى تصبر النفس على تلك المشقة

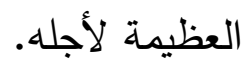
قال الثاعر:

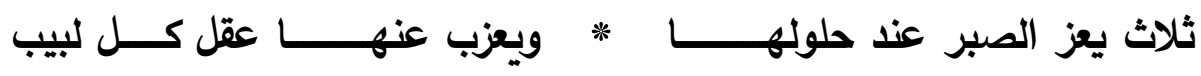

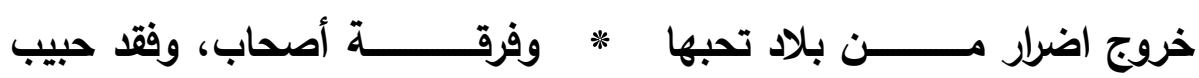
$* * * * * *$

* ومن استنباطات المفسرين أيضا قول الأستاذ الثيخ عبد الحميد بن باديس في تفسيره: (فقد علم الناس من قبل أربعة عشر قرناً أن تربة الوطن معجونـة بريق أبنائه، تشفي من القروح والجروح، ليربط بين تربته وبين قلوبهم عقداً من

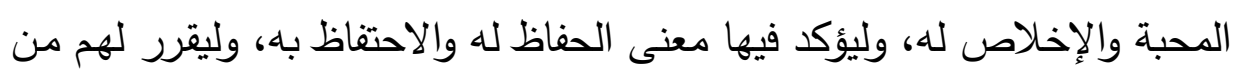
منن الوطن منّة كانوا عنها غـافلين، فقد كانوا يعلمون من علم الفطرة أن تربـة الوطن تغذي وتروي، فجاءهم من علم النبوة أنها تثفي فليس هذا الحديث إرشاداً لمعنى طبي، ولكنه درس في الوطنية عظيم.

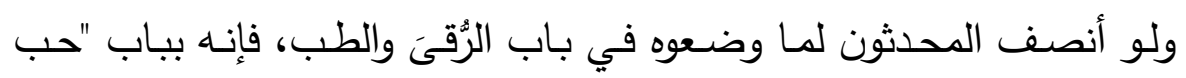
الوطن" أشبه. وما نرى رافع العقيرة بقوله: 


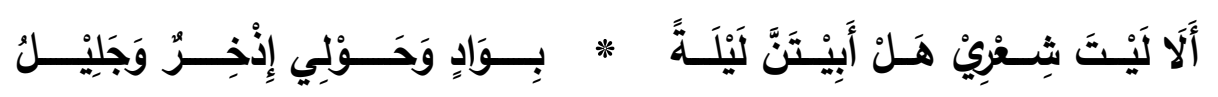

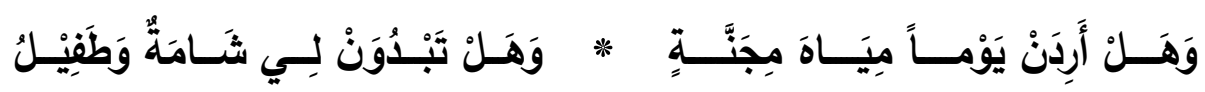
إلاً سائرًا على شعاعه.

وما ترى ذلك الغريب المريض الذي سئل فيم شفاؤك؟ فقال: شمة من تربـة إصطخر ، وشربة من ماء نهاوند، إلاّ من تلامذة هذا الدرس.

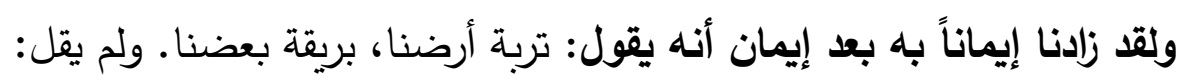

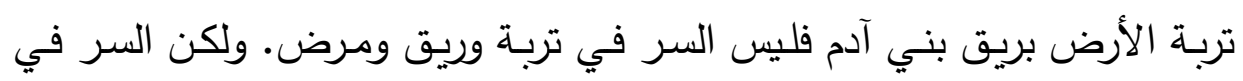

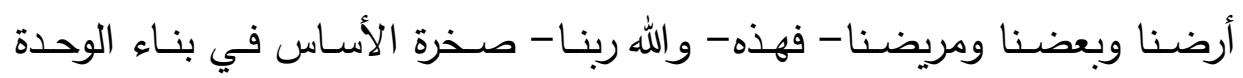
الوطنية والقومية، لا ما يتبجح به المفتونون.

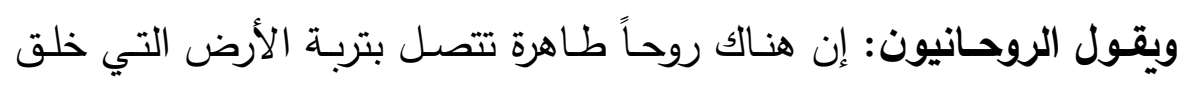
المريض منها، وتغذى بنباتها ومائها، وتنفس كبده في جوها وهوائها، من ريقـه منفوثة نفث الخير ، من نفس مؤمنـة قويـة الروحانية طيبتها، فيكمل التكوين بين الريق والتربة مع اسم الله الذي قامت به السموات والأرض، وصلح عليه أمر الدنيا والآخرة، فيحصل الثفاء بهذا العمل النفساني. وإذا تجلت النفس بعجائبها لم يبق

$$
\text { في الوجود عجيب)('). }
$$

****** $* *$

\section{لمحة من حب الوطن عند الفقهاء:}

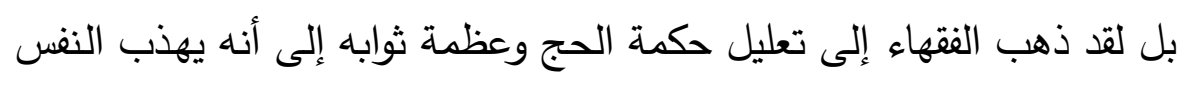
بفراق الوطن، والخروج على المـألوف، قال شيخ السـادة المالكية الإمـام المجتهد الثـهاب أبو العباس أحمد بن إدريس القرافي في: (الذخيرة): (ومصـالح الحجـ: 
تأديب النفس بمفارقة الأوطان، وتهذيبها بالخروج عن المعتاد من المخيط وغيره ليذكر المعاد، والاندراج في الأكفان، وتعظيم شعائر الله تعالى في تلك البقاع) (').

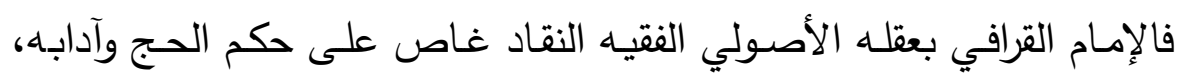

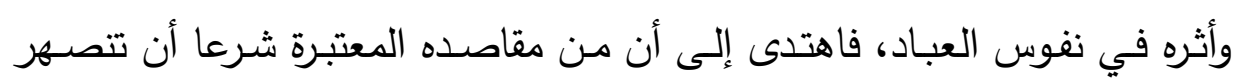

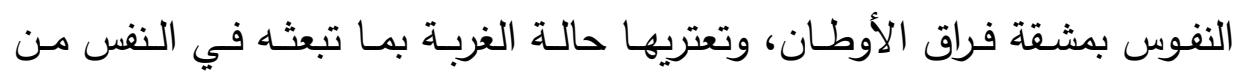

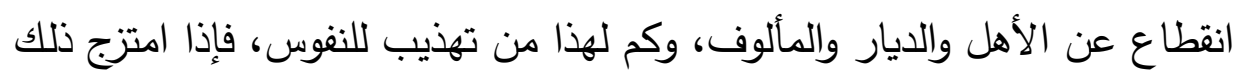

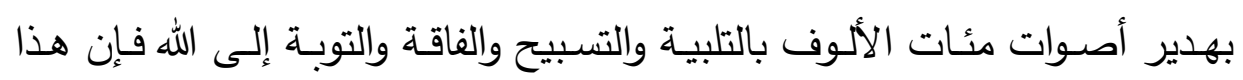
المجموع يحدث في النفس أبلغ الأثر.

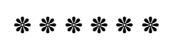

\section{لمحة من حب الوطن عند الأولياء وإلصالحين:}

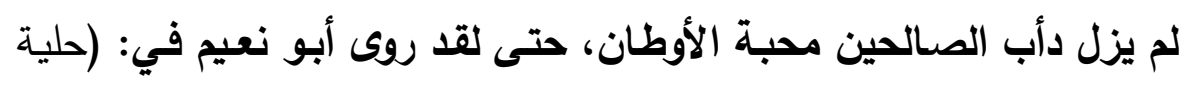

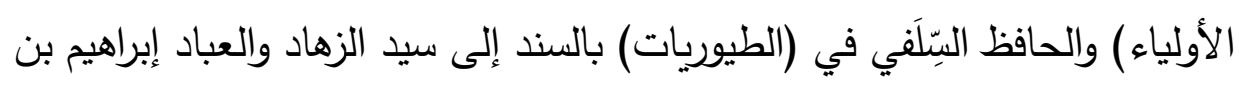

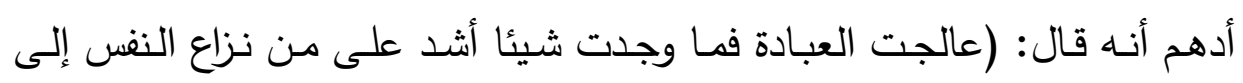

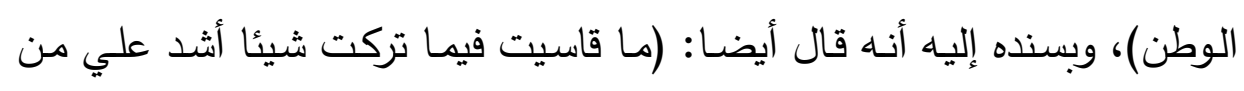

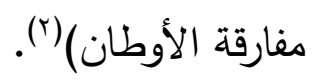

فالناظر إلى هذا الكلام يرى من سيد الزهاد والأصفياء إبراهيم بن أدهم إخبارا

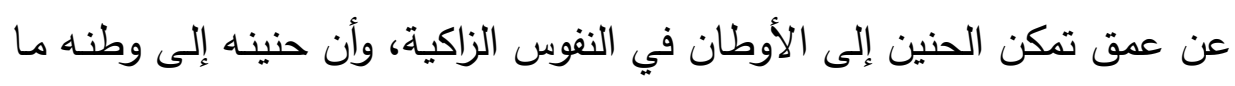

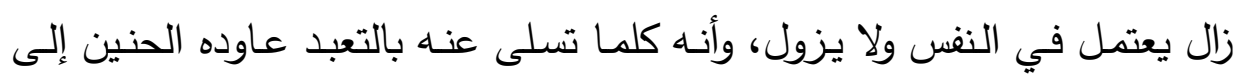

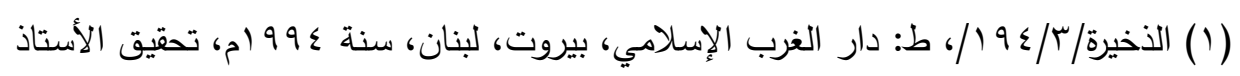

محمد بو خبزة.

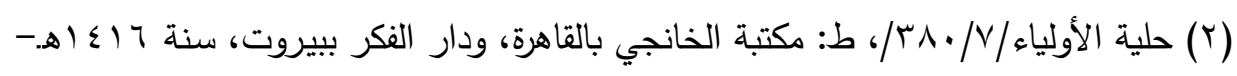

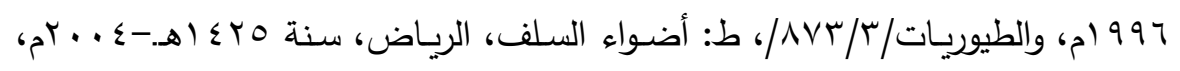
تحقيق دسمان يحيى معالي، وعباس صخر الحسر الحسن. 
الوطن، مما يكثف عن هذا الجانب النبيل الجليل من أحوال الصـالحين القائمين على تزكية الأنفس عن كل معنى ظلماني قبيح، وأن التعلق بالأوطان عندهم كان هن هن معنى شريفا متأصلا لا يزول من النفوس المنيرة ذات العبادة والنسك.

\section{***** $*$ *}

لمحة من حب الوطن عند الحكماء:

وقد روى الاينوري في: (المجالسـة): بسنده أن الأصمعي قال: (قالت الهند: الحِنَّة في ثلاثة أصناف من الحيوان: الإبل تحن إلى أعطانها وإن كان عهدها بهان الإنها

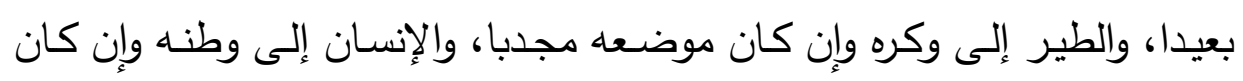

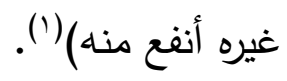
وروى أيضـا مـن طريـق الأصـمعي قـال: سمعت أعرابيا يقول: (إذا أردت أن تعرف الرجل فانظر كيف تحننه إلى أوطانه، وتثوقه إلى إخوانه، وبكاؤه على ما

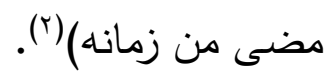

قال أبو عمرو بن العلاء: (مما يدلّ على حريـة الرجل وكرم غريزته: حنينه

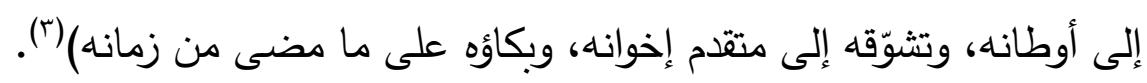
******

لمحة من حب الوطن عند الشعراء والأدباء: ولم يزل الثعراء يبكون ويستبكون، وتجيش منهم الخواطر، وتتحدر منهم روائع البيان في الإعراب عن شدة الحنين والثوق إلى الأوطان، حتى إن الباحث

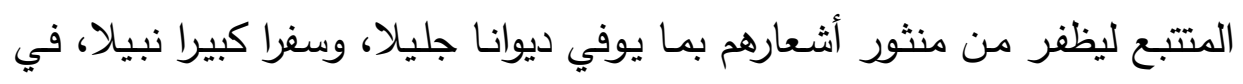

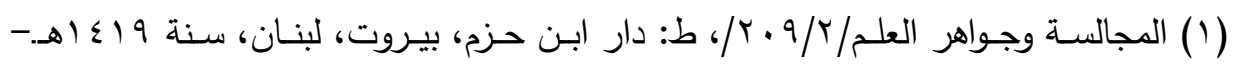

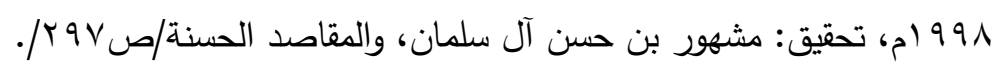

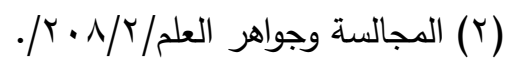

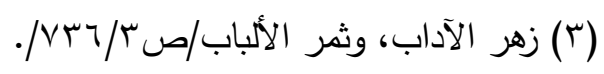


الأشعار الفائقة، والأبيات الرائقة، المعبرة عن شدة فراق الأوطان، على وجدان الإنسان.

بل ربما ترنم بعضهم بشدة الحنين إلى بقاع، هواؤها غير طيب، وماؤها غير عذب، ولا تطيب فيها أسباب الإقامة، ولكنها من وراء ذلك وطن، وحب الوطن يغلب ذلك جميعا، فقال الثاعر:

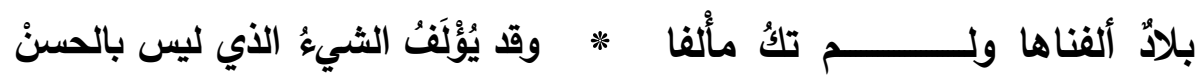

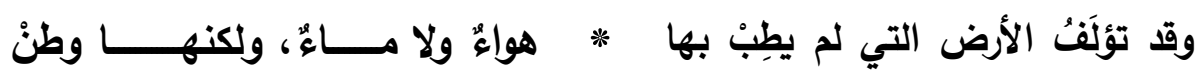
ولأجل هذا الباعث الفطري الكامن في أعماق الإنسـان، فقد عظم الله تعالى شأن الهجرة والمهاجرين، لما اشتملت عليه من مشقة على النفس، ومكابدة لها، بالصبر على فراق الأوطان، ومرابع الصبا، ومعاهد النشأة، فلأجل هذا رتب الله تعالى على الهجرة من الفضل والثواب مـا هو مذكور في القرآن الكريم في غير ولير موضح. وقال ابن بسام في: (الأخيرة): (غير أن الوطن محبوب، والمنشأ مألوف، واللبيب يحن إلى وطنه، حنين النجيب إلى عطنه، والكريم لا يجفو أرضا بها قوابله، ولا ينسى بلدا فيه مراضعه، قال الأول:

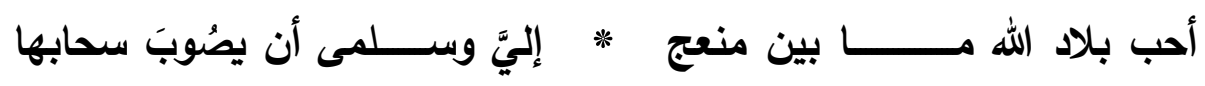

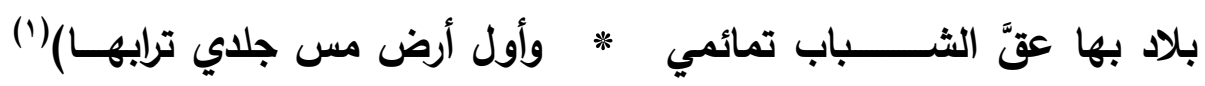
قال صـاحب (ديوان المعـاني): (وذكر ابن الرومي العلة التي يحب الوطن لأجلها وليس له في ذلك إمام إلا أحمد بن إسحاق الموصلي فإنه قال:

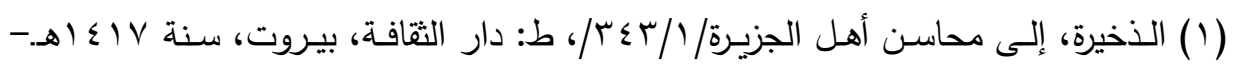
1991 ام، تحقيق: الدكتور إحسان عباس. 


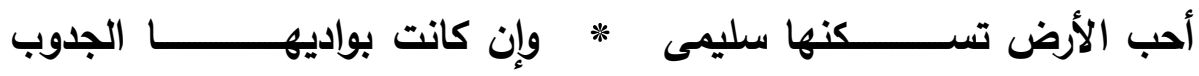

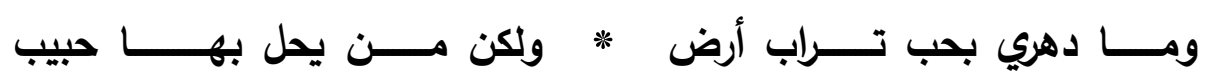
وقال ابن الرومي: - مان

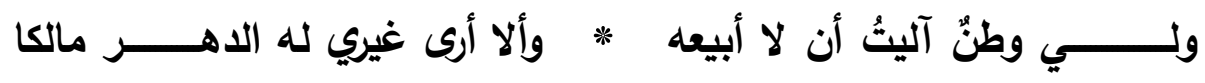

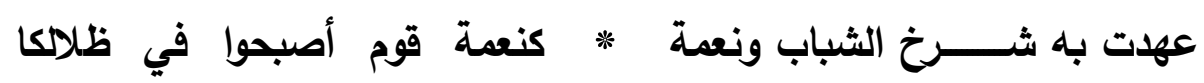

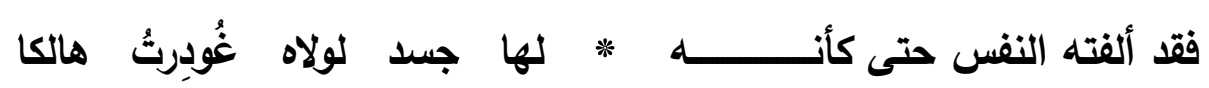

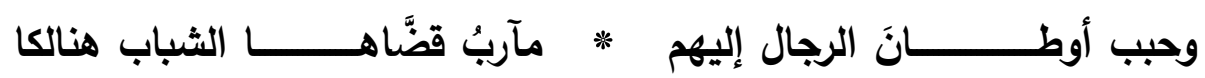

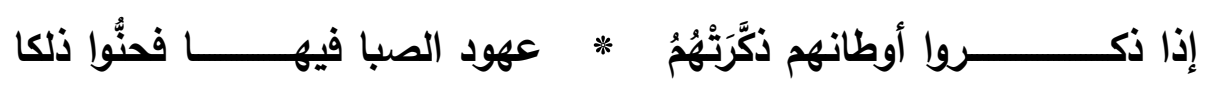

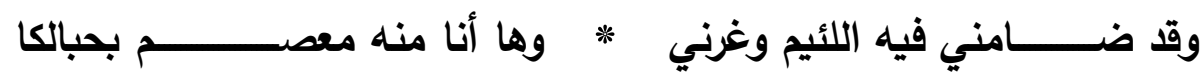

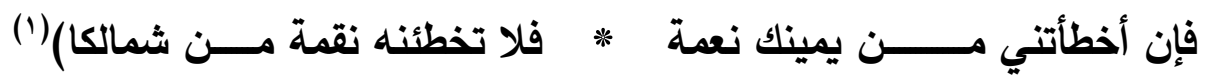
وهذا ختام هذا البحث، حول قيمة الوطن عند المحثثي، والذي أرجو من واسع

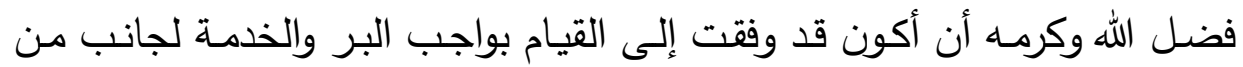
مواريــث النبـوة تشـوه في السـنوات الماضـية، فأوجب على المنسـوبين للحـديث الشريف النهوض إلى إزالة الغبار والسوء عنه، وصلى الله على سيدنا محمد وعلى

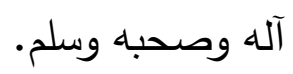

\section{(C)}




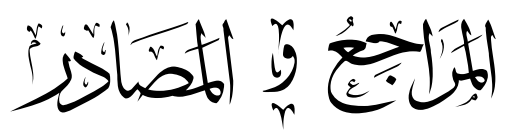

• الإحسـان، في تقريب صـحيح ابن حبان، للأمير عـلاء الدين علي بن بلبان

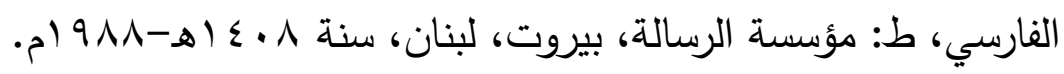

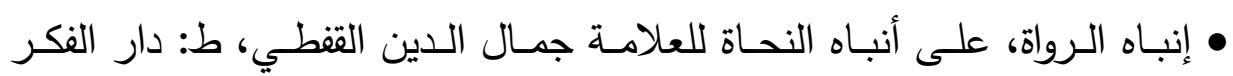

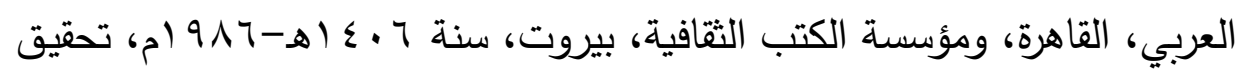
الثيخ محمد أبو الفضل إبراهيم. • الأنسـاب، للإمـام أبي سعد ابن السمعاني، ط: مطبعـة مجلس دائرة المعـارف إيراف

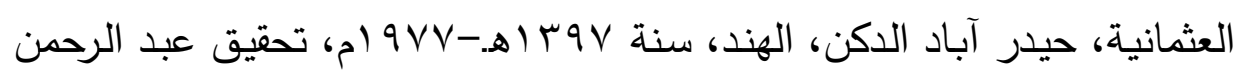

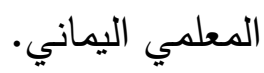
• الأوطان والبلدان للجاحظ، (رسـائل الجاحظ)، ط: دار الجيل، بيروت، لبنـان، تحقيق الأستاذ الثيخ عبد السلام هارون.

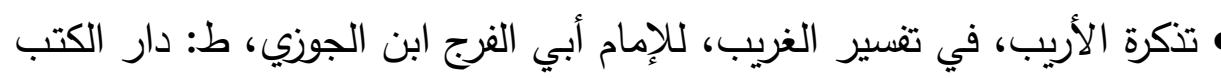

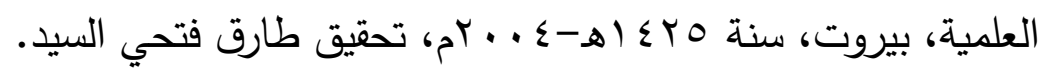

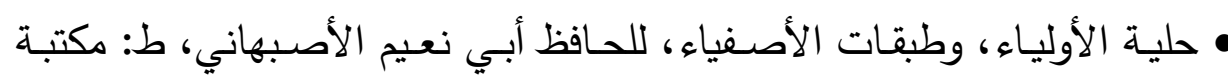
الخانجي بالقاهرة، ودار الفكر ببيروت، سنة 7 إع (هـ-979 (م.

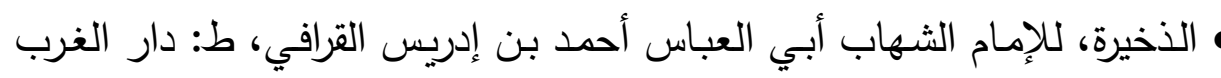

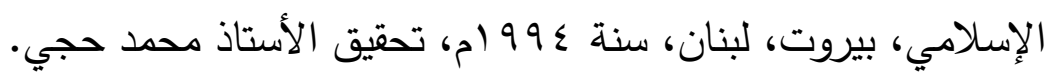
الذخيرة، إلى محاسن أهل الجزيرة، لأبي الحسن علي بن بسام التغلبي، ط: دار

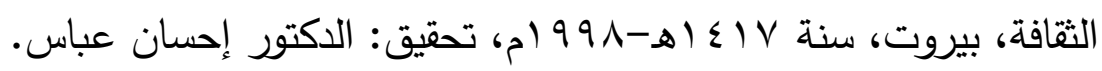

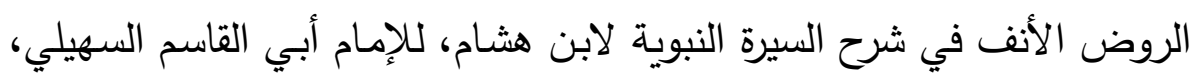

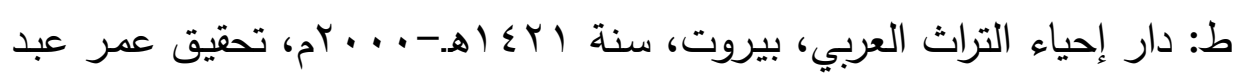

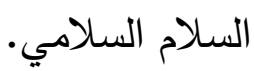


• زاد المسير، في علم التفسير، للإمسام أبي الفرج ابن الجوزي، ط: دار الكتاب العربي، بيروت، سنة ب بـ اهـ، تحقيق عبد الرزاق المهدي.

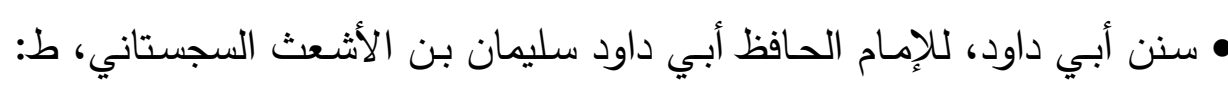

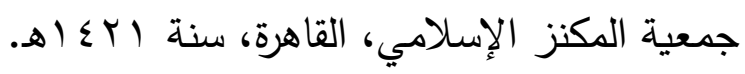

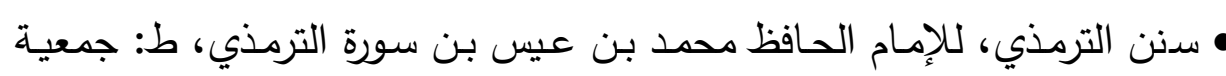

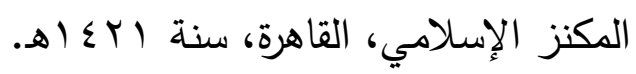
• السنن الكبرى، للإمـام أبي بكر أحمد بـن الحسين البيهقي، طس: دار الكتب الإبله

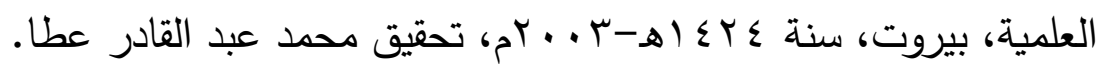

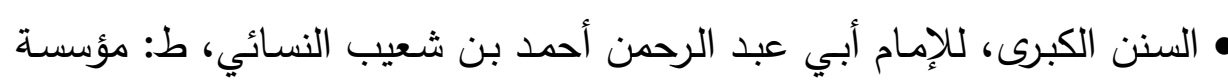

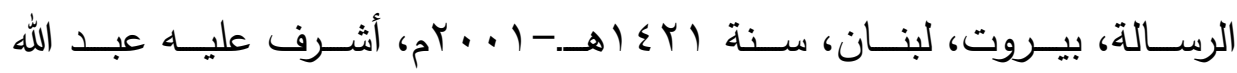
عبد المحسن التركي، حققه وخرج أحاديثه حسن عبد المنعم شلبي. • سيرة الإمام أبي سعد السمعاني التميمي المروزي من كتابه الأنساب، ليحيى بن

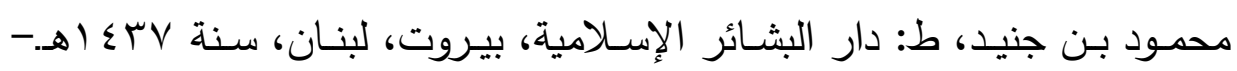
$\cdot{ }^{2}+17$ • شـرح الســنة، للإِمـام المحـدث الحسـين بـن مسـود البغـوي، طب: المكتـب

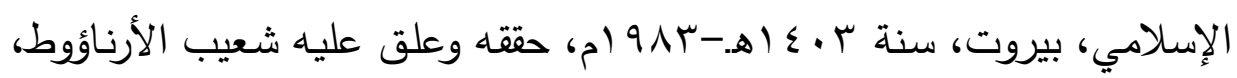
ومحمد زهير الثاويش. • شرح صحيح البخاري للإمام أبي الحسن علي بن خلف بن بطال، ط: مكتبة الرشد، الرياض، المملكة العربية السعودية، سنة ضبط نصه وعلق عليه: أبو تميم ياسر إبراهيم. • شرح مشكل الآثار ، للإمـام أبي جعفر أحمد بن محمد الطحاوي، ط: مؤسسـة الرسالة، بيروت، سنة 0 إ (هـ- 99 (م، تحقيق شعيب الأرنؤوط. 
• صحيح ابن خزيمة، للإمام أبي بكر محمد بن إسحاق بن خزيمة النيسابوري، ط: المكتب الإسـلامي، سنة . . ـ اهـ--919 ام، تحقيق الدكتور محمد مصطفى الأعظمي. - ألمكي.

• صـيح البخاري، لأمير المؤمنين في الحديث الإمـام أبي عبد الله محمد بـن إسماعيل البخاري الجعفي، ط: جمعية المكنز الإسلامي، القاهرة، سنة ابـ اهـ. صـيح مسلم، للإمـام أبي الحسين مسلم بـن الحجـاج القشيري النيسـابوري، ط:

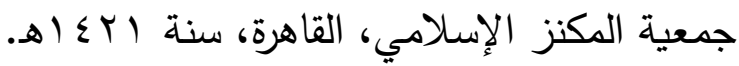

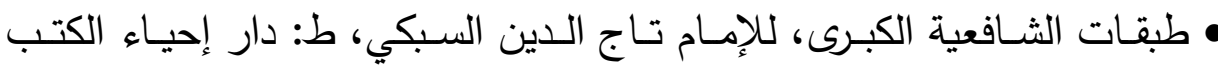
العربية: فيصل عيسى البابي الحلبي، القاهرة، تحقيق: عبد الفتاح محمد الحلو، ومحمود محمد الطناحي. • الطيوريات، من انتخاب الثيخ الأجل الفقيه الإمام الحافظ شيخ الإسـلام وأحد الأنـام فخر الأئمسة أبي طاهر أحمد بن محمد بن أحمد السلفي الأصبهاني من أصسول كتب الثـيخ أبي الحسين بـن المبارك الطيوري الصـيرفي الحنبلي، ط:

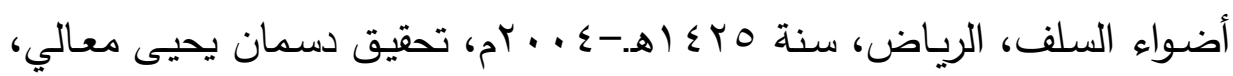
وعباس صخر الحسن. ه الفهرست، لأبي الفرج محمد بن إسحاق المعروف بـابن النديم، طب: مؤسسـة

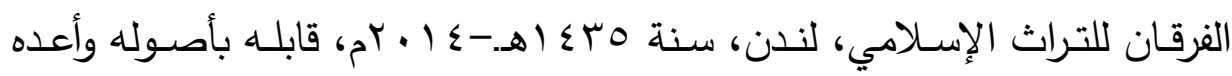
للنشر الدكتور أيمن فؤاد سيد. • فيض القدير، شرح الجامع الصـير، لزين الدين محمد عبد الرؤوف المناوي،

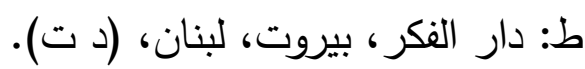
• مثير الغرام السـاكن، إلى أشرف الأمـاكن، للإمـام أبي الفرج ابن الجوزي، طا:

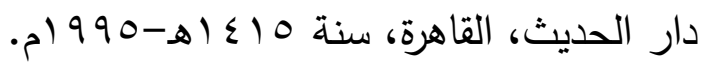


• مجالس التذكير، من كلام الحكيم الخبير، للشيخ عبد الحميد بن باديس، طץ:

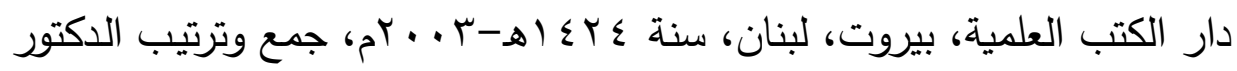
توفيق محمد شاهين، ومحمد الصالح رمضان.

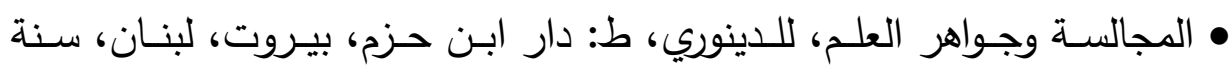
9 (1) (هـ-991 (م، تحقيق: مشهور بن حسن آل سلمان. • المستدرك على الصحيحين، للإمـام أبي عبد الله الحاكم النيسابوري، طب: دار

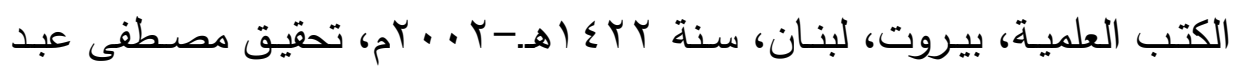
القادر عطا. • مسند الروياني، للحافظ أبي بكر محمد بن هارون الروياني، وبذيله المستدرك

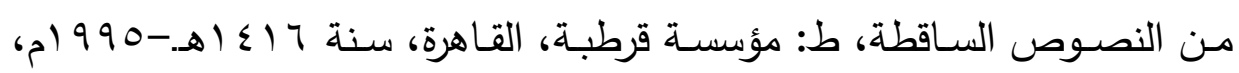
ضبطه وعلق عليه أيمن علي أبو يماني.

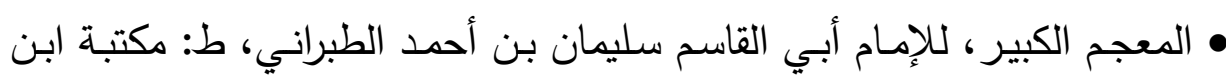
تيمية، القاهرة، (د ت)، تحقيق حمدي عبد المجيد السلفي.

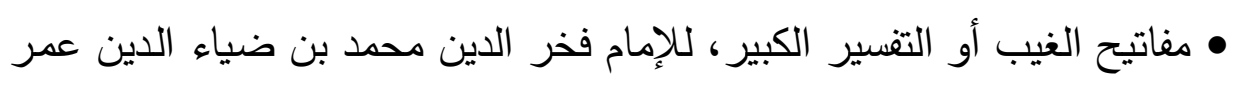

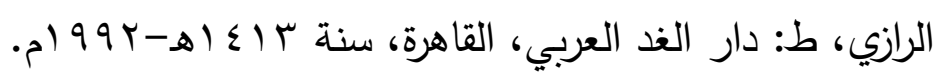

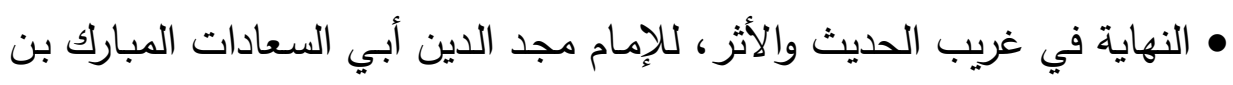
محمد الجزري ابن الأثير، ط: المكتبة الإسلامية، مصر، تحقيق الدكتور محمود محمد الطناحي. • الـوافي بالوفيـات، للعلامـة الصـلاح خليـل بـن أيبك الصـفدي، ط: دار إحيـاء

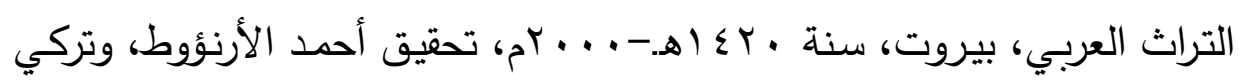
مصطفى. • الوطن والاستيطان دراسـة فقهية، للدكتور محمد موسى مصطفى الدالي، ط:

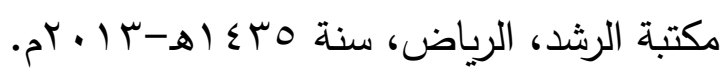


فهرس الموضوعات

\begin{tabular}{|c|c|}
\hline |لصفحة & الموضوع \\
\hline$r$ & الملخص العببي \\
\hline$\varepsilon$ & الملخص الإنجليزي \\
\hline 0 & المقدمة \\
\hline$v$ & 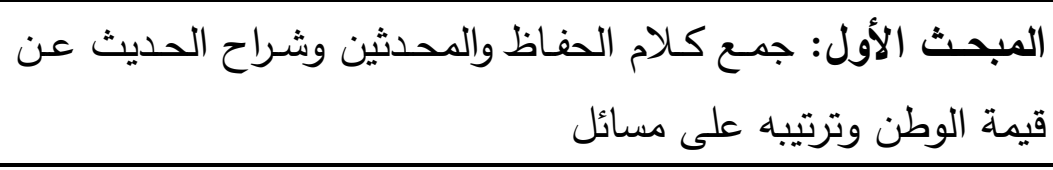 \\
\hline$r$. & 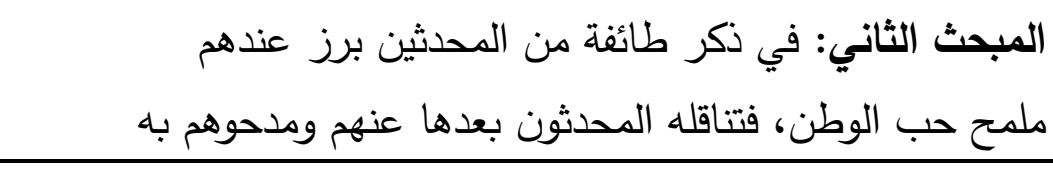 \\
\hline rr & وغيرهم عن الوطن، وأكثر الثصنثين والمؤن في هذات التي أفردها الحفاظ والمحدثون \\
\hline$r$. & أرباب العلوم عن الربابع: في نبذة من كلام المفسرين والفقهاء والزهاد وبقية \\
\hline rq & المصادر والمراجع \\
\hline$\varepsilon r$ & فهرس الموضوعات \\
\hline
\end{tabular}

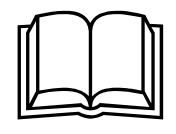

